\title{
How are Antarctic planktonic microbial food webs and algal blooms affected by melting of sea ice? Microcosm simulations
}

\author{
Hanna C. Giesenhagen ${ }^{1, *}$, Andrea E. Detmer ${ }^{1}$, Jürgen de Wall ${ }^{1}$, Anke Weber ${ }^{1}$, \\ Rolf R. Gradinger ${ }^{2}$, Frank J. Jochem ${ }^{1}$ \\ ${ }^{1}$ Institut für Meereskunde, Düsternbrooker Weg 20, 24105 Kiel, Germany \\ ${ }^{2}$ Institut für Polarökologie, Wischhofstraße 1-3, 24148 Kiel, Germany
}

\begin{abstract}
The influence of the melting of Antarctic sea ice on the planktonic microbial food web and the formation of microalgal blooms was investigated under controlled laboratory conditions in 201 microcosms at the onset of austral spring in the southern Atlantic. Experiments were performed with first-year ice and water from the Antarctic Circumpolar Current (ACC) and the ACC-Weddell Gyre Boundary (AWB) at $6^{\circ} \mathrm{W}$, a region usually lacking ice-edge blooms in austral spring. The experiments comprised the following simulations: (1) stratification of the water column, (2) seeding of sympagic organisms, (3) inoculation of dissolved organic matter from sea ice and (4) grazing impact of mesozooplankton (Calanoides acutus). Microcosms were sampled almost daily over a 2 wk period. The samples were analyzed for inorganic nutrient concentrations, primary and bacterial production, abundances of algae (in the size classes $<20$ and $>20 \mu \mathrm{m}$ ), bacterid and heterotrophic flagellates (in the size classes $<2,2$ to 10 and 10 to $20 \mu \mathrm{m}$ ). Additionally, maximum uptake rates of glucose and aminopeptidase activity were measured. Stratification alone did not induce bloom formation within the time scale of the experiments. Simulated seeding of sympagic organisms provoked a strong increase in abundances and activities of auto- and heterotrophic microbes and the development of microalgal blooms icells $>20 \mu \mathrm{m}$ ). Primary and bacterial production was enhanced up to 28-and 24-fold, respectively, compared to the control, while abundances increased by a factor of about 20 for microalgae and 12 for bacteria. Initial high activities of auto- and heterotrophs were restricted to sympagic organisms, which maintained their high metabolic rates for several days. Addition of dissolved organic substances mainly stimulated the pelagic bacterial populations. Their production was enhanced up to 12 -fold compared to the control, while autotrophs were virtually unaffected. In the presence of mesozooplankton, bacterial blooms occurred but no accumulation of nano- and microalgae. Thus, this region of the Atlantic sector of the Southern Ocean does have a strong potential for the formation of ice-edge blooms, but phytoplankton accumulation is efficiently controlled by grazing activity. Bacterial blooms may be more common during ice melt. These findings agree with remote-sensing data, which show no bloom formation during ice melt in this area.
\end{abstract}

KEY WORDS: Antarctica - Marine microbial food web - Algal blooms - DOM - Ice melt - Microcosms

\section{INTRODUCTION}

The microbial food web comprises a significant part of Antartic pelagic (Cota et al. 1990, Kuparinen \& Bjørnsen 1992, Garrison et al. 1993, Jochem et al. 1995) and sea ice communities (Garrison et al. 1986, Kottmeier \& Sullivan 1987, Mathot et al. 1991). Garrison et al. (1986) pointed out the existence of a tightly

•E-mail: hgiesenhagen@ifm.uni-kiel.de coupled microbial food web in sea ice and assumed that associated organisms live in a milieu of elevated dissolved organic matter (DOM) concentrations. The annual ice retreat has a major impact on the formation of ice-edge plankton blooms. Increased stratification by meltwater lenses, shifts in the light regime and possible seeding by ice organisms as inocula for ice-edge blooms have been discussed as possible stimulating factors (Smith \& Nelson 1985, Garrison et al. 1987, Kottmeier \& Sullivan 1990, Scharek 1991). 
The fate of ice organisms upon melting is variable. Sympagic microalgae are subject to severe sedimentation (Riebesell et al. 1991) and grazing by microzooplankton (e.g. Fransz 1988) so that often only small autotrophic cells remain in the water column (Mathot et al. 1991). Besides algae, ice bacterial populations which differ from open water populations (Grossmann \& Gleitz 1993) are seeded together with a population of possible grazers (Kottmeier \& Sullivan 1987, Garrison \& Gowing 1992, Kivi \& Kuosa 1994). While it is thought that in open water smaller phytoplankton and bacterial abundances are effectively controlled by protozooplankton (Garrison \& Buck 1989, Knox 1990, Bjørnsen \& Kuparinen 1991a, Kuparinen \& Bjørnsen 1992) and that microalgae are efficiently grazed by microzoopiankion (́rewes et ai. 1985), uncoupled systems might form during periods of ice melt.

The mechanisms of control and stimulation of iceedge blooms are not fully understood. Most reports on vernal ice-edge blooms as major sources of biomass production were derived from studies in the large Antarctic embayments (Ross and Weddell Seas). However, at the more typically land-remote Antarctic ice edge, microalgal bloom formation upon ice melt may be an exception (Comiso 1991) which could be due to the generally low stabilitiy of the water column (Laubscher et al. 1993). Macronutrients are apparently not limiting for growth in this high-nutrient low-chlorophyll area, whereas micronutrients (Martin et al. 1990) and dissolved organic matter (DOM) may be more important. The possible development of blooms composed of pico- and nanoplanktonic-sized organisms points towards the importance of DOM released from melting ice. DOM is known to occur in vast concentrations within ice and the underlying waters and to be rapidly used by bacteria (Kähler et al. 1997) which in turn may provide substances for phytoplankton growth (Kuosa et al. 1992), e.g. cytokins (Delucca \& McCracken 1977 ) or siderophores. The effect of sea ice DOM on the microbial community during ice melt has not yet received much attention.

Satellite images have repeatedly shown that in some regions of the Antartic Ocean autotrophic bloom development upon ice melt is a recurrent phenomenon, while it is not in other regions. It is unclear if in the latter areas mass accumulation by algae is replaced by blooming heterotrophs or if blooms of any type are lacking. This study presents information on factors controlling the formation of ice-edge blooms and the effect of sea ice DOM derived from microcosm experiments. Water and ice samples from a non-bloom region, here the transition zone between the Antarctic Circumpolar Current and the Weddell-Gyre water around $6^{\circ} \mathrm{W}$, were used to assess the fate of microorganisms upon ice melt. Special emphasis was placed on resolving the reaction of auto- and heterotrophic organisms of the pico and nano size fraction following this event.

\section{MATERIALS AND METHODS}

Sampling and experimental design. Batch cultures were established on the RV 'Polarstern' cruise ANT X/6 in 1992 with natural plankton communities from 3 stations in the Atlantic sector of the Southern Ocean at the onset of austral spring, $6^{\circ} \mathrm{W}$ near the ice edge. Stations were located in the Antarctic Circumpolar Current (ACC) and the ACC-Weddell Gyre Boundary (AWB). Further details are given in Table 1. A general description of the area and the cruise can be obtained from Smetacek et al. (1997). Water samples were taken from $20 \mathrm{~m}$ depth by Niskin bottles, pre-screened through a $200 \mu \mathrm{m}$ net and transferred to $20 \mathrm{l}$ polycarbonate microcosms (MCs).

Cubes of brown ice chosen by colour were split and transferred either into a dialysis bag with a retention of $0.2 \mu \mathrm{m}$ or into a plastic bag. Bags were placed in sinks with running sea surface water and the ice slowly melted for 8 to $10 \mathrm{~h}$ at $-1^{\circ} \mathrm{C}$. The meltwater in the dialysis bags contained the mixed assemblage of ice biota, i.e. the so-called 'sympagic' community and an unknown amount of DOM. The use of dialysis bags for harvesting ice biota can be taken as a modification of the method suggested by Garrison \& Buck (1986). The directly melted ice was filtered through $0.2 \mu \mathrm{m}$ polycarbonate filters and contained by definition DOM from sea ice only ('DOM' meltwater). The amount of

Table 1. Sampling conditions for batch experiments. Temperature (T), salinity (S), chlorophyll a (Chl a) concentration at $20 \mathrm{~m}$ depth and ice cover (\% ice cover) provided by C. Veth, U. Bathmann and J. van Franeker (pers. comm.). ACC = Antarctic Circumpolar Current waters; AWB = ACC-Weddell Gyre Boundary waters; UTC = universal time coordinated

\begin{tabular}{|c|c|c|c|c|c|c|c|c|c|}
\hline Expt & Stn & Position & $\begin{array}{c}\text { Date } \\
(1992)\end{array}$ & $\begin{array}{l}\text { Time } \\
\text { (UTC) }\end{array}$ & $\begin{array}{c}\mathrm{T} \\
\left({ }^{\circ} \mathrm{C}\right)\end{array}$ & $\begin{array}{c}\text { S } \\
\text { (psu) }\end{array}$ & $\begin{array}{c}C h l a \\
\left(\mu \mathrm{gl}^{-1}\right)\end{array}$ & $\begin{array}{l}\% \text { ice } \\
\text { cover }\end{array}$ & $\begin{array}{c}\text { Type of } \\
\text { water }\end{array}$ \\
\hline 1 & 866 & $57^{\circ} 45^{\prime} \mathrm{S}, 6^{\circ} 28^{\prime} \mathrm{W}$ & 11 Oct & $22: 00$ & -1.82 & 34.06 & 0.17 & 95 & AWB \\
\hline 2 & 874 & $54^{\circ} 00^{\prime} \mathrm{S}, 6^{\circ} 00^{\prime} \mathrm{W}$ & $15 \mathrm{Oct}$ & $04: 00$ & -1.67 & 33.94 & 0.24 & 0 & $\mathrm{ACC}$ \\
\hline 3 & 915 & $57^{\circ} 30^{\prime} \mathrm{S}, 6^{\circ} 00^{\prime} \mathrm{W}$ & 04 Nov & $14: 00$ & -1.55 & 33.82 & 0.38 & 70 & AWB \\
\hline
\end{tabular}


DOM was probably raised by the crude method used for ice melting which may have caused cell damage. However, the experiments were not designed to simulate changes on a natural level but for clear distinction between effects of different treatments. MCs were established by mixing 1.5 to 1.7 I 'sympagic' or 'DOM' meltwater with seawater to a final volume of 201 (Table 2). All MCs were incubated at in situ temperature $\left(-1^{\circ} \mathrm{C}\right)$ and a $14: 10 \mathrm{~h}$ light:dark cycle on board RV

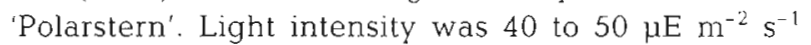
Subsampling of the microcosms started at 10:00 h local time on the respective days.

Expt 1: The first experimental series lasted $12 \mathrm{~d}$ and included 6 different manipulations (Table 2). AWB water was stored prior to the experiment under the conditions described above

MC1 (without meltwater) served as a control. MC2 (without meltwater) was kept under a $4: 4 \mathrm{~h}$ light:dark cycle during the light period to simulate turbulent mixing of the plankton community into deeper water layers or periods of shading by drifting ice floes. The remaining $\mathrm{MCs}$ were set up to investigate the impact of either 'seeding' by ice biota (MC4, MC6) or DOM 'inoculation' (MC3, MC5) on the development of under-ice AWB water and ice-free ACC water. Since AWB and ACC waters differed in, for example, initial nutrient concentration and dissolved organic carbon (DOC) content (Kähler et al. 1997), our experiments simulated the effect of ice retreat on different pelagic communities. ACC water otherwise showed, for example, neither qualitative nor quantitative differences in phytoplankton composition compared to AWB water (Jochem et al. 1995). Bacterial abundances were also rather similar (Lochte et al. 1997). Therefore, only 1 $\mathrm{MC}$ with under-ice AWB water was used as a control for evaluating the effects of seeding and DOM inoculation on both types of water.
Prior to sampling, the MCs were gently shaken. To address and compare the effect of seeding versus DOM inoculation it had to be secured that all organic material in the MCs was evenly distributed to avoid artefacts caused by sedimentation. Since it was impossible to continuously mechanically shake the large microcosms this was reduced to shaking by hand once per day followed by subsampling. Large flocks of undisruptable flocculent material developed and sometimes prevented counting of dispersed organisms in the first experiment.

Expt 2: Expt 2 included 4 different manipulations and lasted $14 \mathrm{~d}$ (Table 2). Effects of sedimentation of microalgae and copepod grazing on the added sympagic community (MC7) and on natural communities of AWB waters (MC9) in a stabilised water column were simulated. Consequently, MCs were not shaken during Expt 2 to avoid resuspension of aggregates and thereby reintroducing them into the experiment. Under natural conditions these would have sedimented out of the surface layer and not contributed to the possible development of an autotrophic bloom. Adult copepods of the species Calanoides acutus were added according to total copepod abundances found at the ice edge $\left(500 \mathrm{~m}^{-3}\right.$; Dubischar pers. comm.). MC8 and MC10 also contained AWB water with and without ice biota, but without copepods.

Measured variables. Phosphate, nitrate and silicate concentrations were determined according to Grasshoff et al. (1983) with a Technicon AA II auto analyser.

Primary production was measured by the carbon ${ }^{14} \mathrm{C}$-technique (Steemann Nielsen 1952) using $50 \mu \mathrm{Ci}$ of $\mathrm{NaH}^{14} \mathrm{CO}_{3} 250 \mathrm{ml}^{-1}$. Samples were incubated for $6 \mathrm{~h}$ under the same light and temperature conditions as were the microcosms. The reaction was stopped by addition of $2.5 \mathrm{ml} 10^{-5} \mathrm{M}$ 3-(3,4-dichlorophenyl)-1,1dimethylurea (DCMU) and samples were filtered onto

Table 2. Set-up of Expts 1 and 2. ACC = Antarctic Circumpolar Current; AWB = ACC-Weddell Gyre Boundary; DOM = dissolved organic matter; $\mathrm{MC}=$ microcosm $_{i}<0.2 \mu \mathrm{m}=$ ice melted in a plastic bag, the $0.2 \mu \mathrm{m}$ filtrate was used $>0.2 \mu \mathrm{m}=i \mathrm{ce}$ melted in a dialysis bag with a retention of $0.2 \mu \mathrm{m}_{i}$ light:dark $=4: 4 \mathrm{~h}$ light/dark cycle during the $14 \mathrm{~h}$ light period (see text)

\begin{tabular}{|c|c|c|c|c|}
\hline & Microcosm & Type of water & $\begin{array}{l}\text { Additions } \\
\text { of melted ice and copepods } \\
\text { (Calanoides acutus) }\end{array}$ & Comments \\
\hline \multirow[t]{6}{*}{ Expt 1} & $\mathrm{MC1}$ & AWB,$<200 \mu \mathrm{m}$ & - & Control \\
\hline & $\mathrm{MC2}$ & $\mathrm{AWB},<200 \mu \mathrm{m}$ & - & Light:dark (deep mixing simulation) \\
\hline & MC3 & AWB,$<200 \mu \mathrm{m}$ & $1.7 \mathrm{l}<0.2 \mu \mathrm{m}$ & DOM addition \\
\hline & MC4 & AWB,$<200 \mu \mathrm{m}$ & $1.5 \mathrm{l}>0.2 \mu \mathrm{m}$ & Ice biota addition \\
\hline & MC5 & $\mathrm{ACC},<200 \mu \mathrm{m}$ & $1.7 \mathrm{l}<0.2 \mu \mathrm{m}$ & DOM addition \\
\hline & MC6 & $\mathrm{ACC},<200 \mu \mathrm{m}$ & $1.5 \mathrm{l}>0.2 \mu \mathrm{m}$ & Ice biota addition \\
\hline \multirow[t]{4}{*}{ Expt 2} & $\mathrm{MC7}$ & $\mathrm{AWB},<200 \mu \mathrm{m}$ & $1.6 \mathrm{l}>0.2 \mu \mathrm{m}, 10$ copepods & Ice biota addition + grazing impact \\
\hline & MC8 & $\mathrm{AWB},<200 \mu \mathrm{m}$ & $1.6 \mathrm{l}>0.2 \mu \mathrm{m}$ & Ice biota addition \\
\hline & MC9 & AWB,$<200 \mu \mathrm{m}$ & 11 copepods & Grazing impact \\
\hline & MC10 & $\mathrm{AWB},<200 \mu \mathrm{m}$ & - & Control \\
\hline
\end{tabular}


$0.2 \mu \mathrm{m}$ membrane filters. Samples with $10^{-5} \mathrm{M}$ DCMU amendment prior to carbon ${ }^{14} \mathrm{C}$ addition served as dark values (Legendre et al. 1983). Filters were transferred into Lumagel SB (Baker) scintillation cocktail and radioassayed in a Beckmann LS-1800 liquid scintillation counter.

Bacterial production was estimated by incorporation of ${ }^{3} \mathrm{H}$-leucine (TLI) (Kirchman et al. 1985) at a final concentration of $100 \mathrm{nM}$ (specific activity: $145 \mathrm{Ci} \mathrm{mmol}{ }^{-1}$, DuPont NEN) and by incorporation of $\left({ }^{3} \mathrm{H}\right.$-methyl)thymidine (TTI) (specific activity: $74 \mathrm{Ci} \mathrm{mmol}^{-1}$. DuPont NEN) at a final concentration of 5 to $10 \mathrm{nM}$ (Fuhrman \& Azam 1982). Saturation levels were checked on the first subsampling date. Triplicate $10 \mathrm{ml}$ subsamples and 1 blank (formalin killed sample) werc incubated for 60 to $120 \mathrm{~min}$ at $1^{\circ} \mathrm{C}$. Incubation was stopped by adding $100,1137 \%$ formalin. Samples were filtered onto $0.2 \mu \mathrm{m}$ polycarbonate fil-

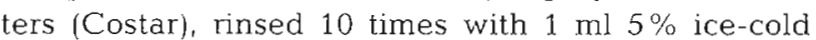
trichloroacetic acid (TCA) and analysed as described for primary production. Counts were corrected for quenching by external standardization. Hot TCA extraction was not performed in the determination of TLI to correct for labelling other than that to proteins (Simon \& Azam 1989). For calculating the bacterial secondary production, a conversion factor of $3.0 \mathrm{~kg}$ $\mathrm{C} \mathrm{mol}{ }^{-1}$ leucine and a factor of $1.110^{18} \mathrm{cells} \mathrm{mol}^{-1}$ thymidine (Bjørnsen \& Kuparinen 1991b) multiplied by the mean carbon content per cell of the respective sample were used.

Heterotrophic maximum uptake velocity of ${ }^{3} \mathrm{H}$-glucose was measured as described by Gocke (1975). Triplicate $20 \mathrm{ml}$ subsamples and one blank received $3 \mu \mathrm{Ci}$ of tritiated (specific activity: $17.7 \mathrm{Ci} \mathrm{mmol}^{-1}$, DuPont NEN) and $20 \mu \mathrm{g} \mathrm{Cl}^{-1}$ unlabelled glucose. After 2 to $4 \mathrm{~h}$ incubation at $-1^{\circ} \mathrm{C}$ samples were fixed with $100 \mu \mathrm{l} 37 \%$ formalin, filtered onto $0.2 \mu \mathrm{m}$ acetate filters (Sartorius), rinsed 2 times with $3 \mathrm{ml}$ prefiltered sea water and radioassayed as described above.

Extracellular aminopeptidase activity was measured by addition of the fluorigenic model substrate 4,7 leucine-methylcoumarinylamide (Leu-MCA; Hoppe 1993) with a Kontron SFM 25 fluorometer (excitation $364 \mathrm{~nm}$, emission $445 \mathrm{~nm}$ ). Fluorescence was read twice from triplicate $2.5 \mathrm{ml}$ samples with final substrate concentrations of $0.1,1,10$ and $100 \mu \mathrm{M}$, once right after addition of Leu-MCA and again after 4 to $6 \mathrm{~h}$ incubation. Values for maximum hydrolysis, hydrolysis rate and the affinity parameter $K_{\mathrm{t}}+S_{\mathrm{n}}\left(K_{\mathrm{t}}=\right.$ half saturation constant; $S_{\mathrm{n}}=$ natural substrate concentration) were calculated from linear transformation of the saturation curve (Hoppe 1993).

For enumeration of abundances of auto- and heterotrophic plankton, samples were fixed with glutaraldehyde (final concentration $0.3 \%$ ) and filtered onto $0.2 \mu \mathrm{m}$ Sudan Black prestained polycarbonate filters (Costar), except for heterotrophic flagellates $(0.8 \mu \mathrm{m}$ filters). For bacteria $0.03 \% \mathrm{w} / \mathrm{v}$ Acridine orange (AO) staining (Zimmermann 1977, Porter \& Feig 1980) was used, for autotrophic cells we used $0.033 \% \mathrm{w} / \mathrm{v}$ Proflavine (Haas 1982) and for heterotrophic flagellates a combination of Proflavine and $10 \mu \mathrm{M}$ Hoechst 33342 staining was applied. This combination of dyes allowed us to check the presence of nuclei in very small organisms. A minimum of 200 autotrophic cells or bacteria, respectively, was counted in at least 20 fields, resulting in a counting error of $< \pm 10 \%$ (Venrick 1978). Autotrophic cells were divided into size classes of nano- and picoalgae $(<20 \mu \mathrm{m}$, ANP, APP) and microalgae $(>20 \mu \mathrm{m})$. For enumeration of heterotrophic flagellates 50 to 100 cells in 60 to 120 fields were counted, which distinguished picoflagellates $(<2 \mu \mathrm{m}, \mathrm{HPF})$ and nanoflagellates $(2$ to 10 and 10 to $20 \mu \mathrm{m}_{i}$ HNF). All filters were analysed within a few days on board RV 'Polarstern' with a Zeiss Axioscope epifluorescence microscope using blue-light excitation (450 to $490 \mathrm{~nm}$ ) for $\mathrm{AO}$ and Proflavine and UV excitation ( $365 \mathrm{~nm}$ ) for Hoechst 33342 stained samples.

Bacterial biovolume was estimated by fitting the length and the width of 50 individual cells of each sample to the circles of a New Porton G12 grid (Graticules Ltd, UK). Biovolume was converted into bacterial carbon using the formula $\mathrm{CC}=88.6 \times \mathrm{vol}^{0.59} \times 1.042$ (Simon \& Azam 1989), where CC and vol are the average carbon content per cell ( $\mathrm{fg} C \mathrm{Cell}^{-1}$ ) and the average cell volume $\left(\mu \mathrm{m}^{3}\right)$, respectively.

Statistical analyses. Manipulations could only be performed without parallel set-ups. Though we have estimates of the accuracy of the different methods used (standard errors of about $10 \%$ for abundances and volume estimates and $<5 \%$ for activity measurements), no reliable variance for the specific variables in the manipulations can be given. To check whether the time courses of the investigated variables were significantly different among the treatments, a non-parametric Wilcoxon signed rank test was performed (StatView 4.1; Abacus Concepts). The p-values presented are based on this test and always refer to a comparison with the respective control set-up.

\section{RESULTS}

\section{Expt 1}

Nutrients. Initial nutrient concentrations of the AWB and $\mathrm{ACC}$ (Fig. 1) water were rather similar except for silicate, where AWB water (MC1 to MC4) exhibited higher concentrations than $\mathrm{ACC}$ water (MC5 and 
MC6). In MC4 and MC6 (addition of sympagic biota) nutrients decreased during the experiment and nitrate and silicate were exhausted at the end. In the other MCs, only a slight uptake of nutrients was measurable starting from Day 8
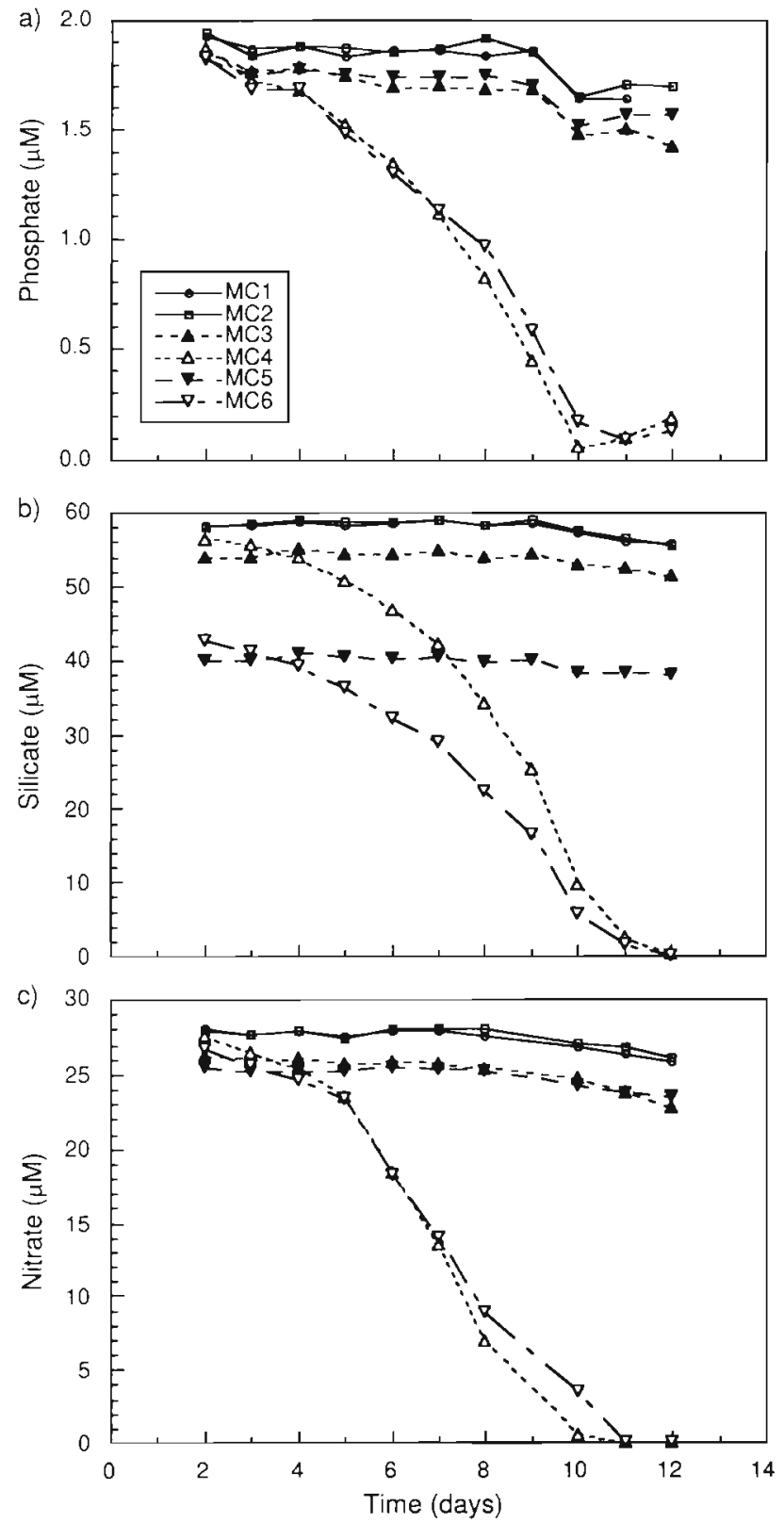

Fig. 1. Time course of nutrient concentrations in Expt 1. (0) $\mathrm{MC} 1=$ control, $200 \mu \mathrm{m}$ pre-screened AWB water; $(\square) \mathrm{MC} 2$ $=200 \mu \mathrm{m}$ pre-screened AWB water and $4: 4 \mathrm{~h}$ light:dark cycle; (ム) $\mathrm{MC} 3=200 \mu \mathrm{m}$ pre-screened $\mathrm{AWB}$ water and DOM; (C) $\mathrm{MC4}=200 \mu \mathrm{m}$ pre-screened AWB water and sympagic organisms; $(\nabla) \mathrm{MC5}=200 \mu \mathrm{m}$ pre-screened ACC water and DOM; $(\nabla)$ MC6 $=200 \mu \mathrm{m}$ pre-screened $\mathrm{ACC}$ water and sympagic organisms. $\mathrm{ACC}=$ Antarctic Circumpolar Current, AWB $=$ ACC-Weddell Gyre Boundary

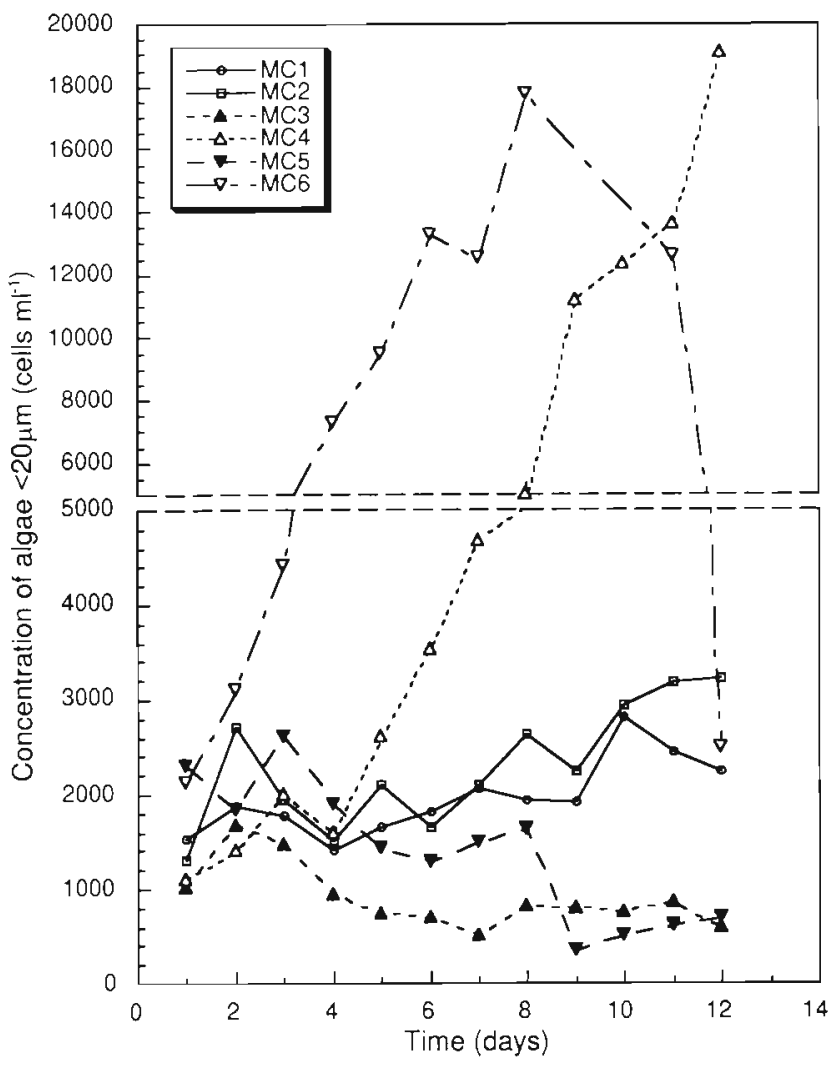

Fig. 2. Time course of autotrophic pico- and nanoplankton abundance in Expt 1. For further details see Fig. 1

Phytoplankton abundances and growth. Initial abundances of phototrophic pico- and nanoplankton (APP and ANP) in ACC water (Fig. 2) with values of 2130 (MC6) and 2310 cells $\mathrm{ml}^{-1}$ (MC5) were higher than in the AWB treatments (1030 to 1530 cells $\mathrm{ml}^{-1}$ ). In ACC water, APP and ANP increased without apparent lag phase. The concentration of phototrophic cells $>20 \mu \mathrm{m}$ (Fig. 3) was initially below the detection limit in all treatments except for those with ice biota addition, where concentrations of 530 (MC6) and 750 cells $\mathrm{ml}^{-1}$ (MC4) were observed. This size class, which started to grow after Day 5, was dominated by diatoms of the genera Chaetoceros and Nitzschia.

The highest growth rates of phytoplankton $<20 \mu \mathrm{m}$ $\left(0.27\right.$ and $\left.0.08 \mathrm{~d}^{-1}\right)$ calculated over the entire length of the experiment occurred in treatments MC4 and MC6 with added sea ice biota (Fig. 4). Abundances of this size class decreased in treatments with added DOM ( $\mathrm{p}=0.002$ for MC1 vs MC3). Taxa $>20 \mu \mathrm{m}$ exhibited higher positive growth rates in all microcosms and only negligible differences were found in treatments MC3 to MC6 (data range: 0.48 to $0.51 \mathrm{~d}^{-1}$ ). Microalgal accumulation was significantly different to the control in MC3 ( $p=0.03)$, MC4 and MC6 ( $p=0.002$ in both cases). 


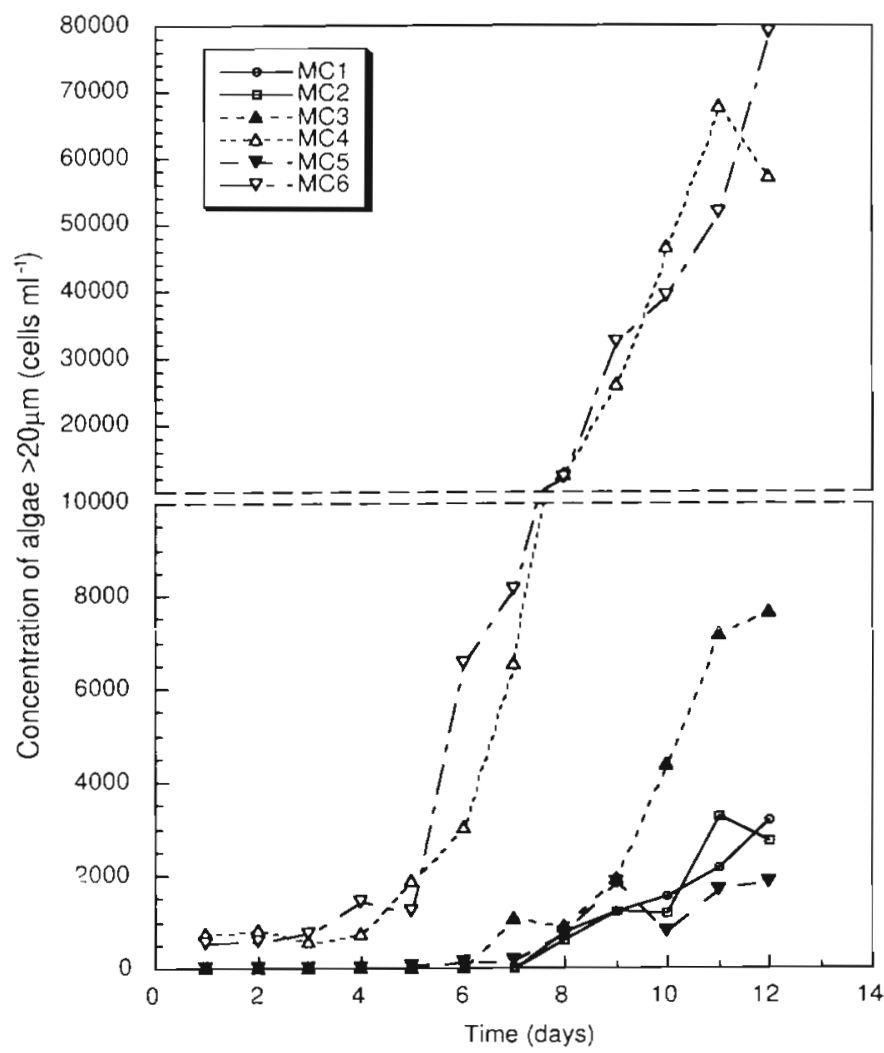

Fig. 3. Time course of microalgal abundances in Expt 1. For further details see Fig. 1

The highest rates of primary production of about $15 \mu \mathrm{C}^{-1} \mathrm{~h}^{-1}$ were measured in MC4 and MC6, which contained ice biota (Fig. 5). In contrast to the other biological parameters, primary production in $\mathrm{MC4}$ and MC6 increased sharply after Day 4. Maximum rates of primary production towards the end of the time series corresponded well to increasing standing stocks of microalgae. However, primary production rates in MCs containing ice biota decreased markedly by Days 9 to 10. This was reflected by a decrease in ANP and APP abundances in MC6, whereas algae continued to acculumate in $\mathrm{MC} 4$. The increase in primary production in MC3 with added DOM towards the end of the experiment was not significant according to Wilcoxon test. In this treatment the significant increase in microalgae was most likely counterbalanced by the significant decrease of APP and ANP.

Bacterial abundances and growth. Initial bacterial abundances in AWB and ACC waters were as low as 6 to $7 \times 10^{4}$ and 11 to $13 \times 10^{4}$ cells $\mathrm{ml}^{-1}$, respectively (Fig. 6a). Numbers were roughly doubled by the addition of ice biota and increased instantaneously in these treatments ( $\mathrm{MC4}$ and $\mathrm{MC} 6$ ), with initial growth rates of up to $0.6 \mathrm{~d}^{1}$ (Fig 4). Abundances in all ice treatments significantly increased by a factor of $20(p=0.003$ to
0.02). Very large bacterial cells were observed in MCs with sea ice biota, which significantly raised the initial mean cell carbon content (Fig. 6b).

Incorporation rates of either tritiated thymidine or leucine (TTI, TLI) increased instantly in all MCs (Fig. 7a,b). Initial rates of about $1 \mathrm{pM} \mathrm{h}^{-1}$ for TTI and 119 to $166 \mathrm{pM} \mathrm{h}^{-1}$ for TLI in MCs containing the sympagic community were roughly 10 times higher than in the other microcosms. After Day 4, TTI and TLI developed differently in sympagic and DOM treatments. While TTI showed maximum rates in set-ups with additional DOC (MC3 and MC5), TL.I was highest in the MCs with added ice biota. Obviously both bacteria from ice and planktonic bacteria had started to grow. The development of bacterial abundances in all ice treatments was signiticantly ditterent to the control $(\mathrm{p}=0.008$ to 0.05 ). Although TTI and TLI rates developed differently in the MCs, per cell activities followed a similar pattern; initially (Days 1 to 2 ), per cell activities

a)

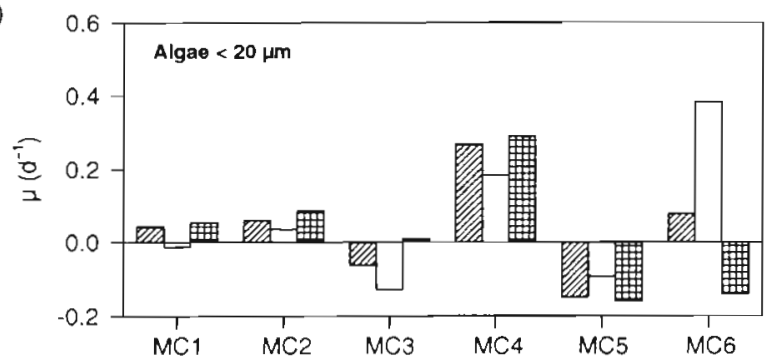

b)

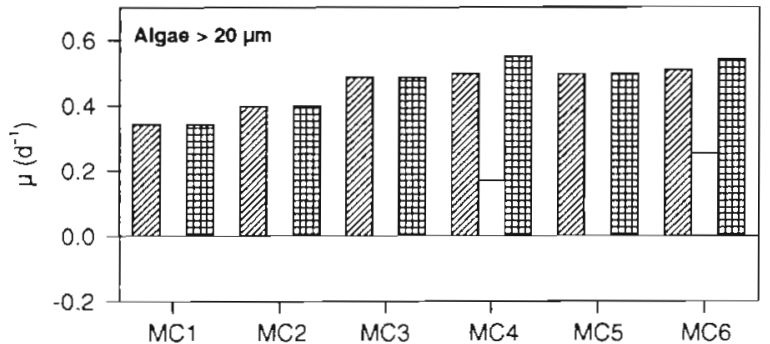

c)

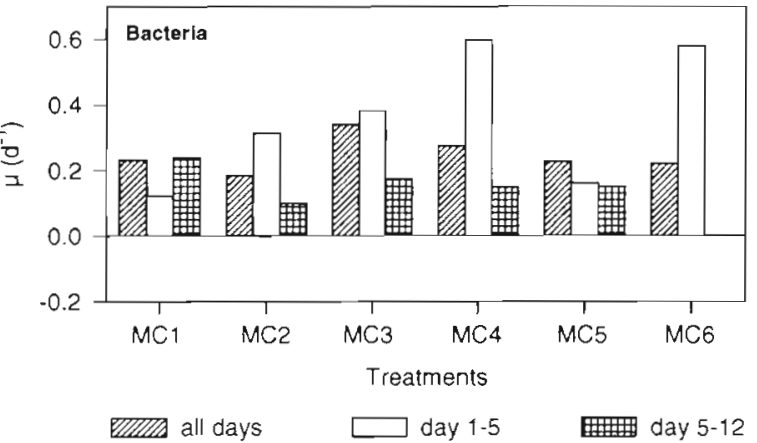

Fig. 4. Apparent growth rates of (a) algae $<20 \mu \mathrm{m}$, (b) algae $>20 \mu \mathrm{m}$ and (c) bacteria during Expt 1. Growth rates were calculated for the entire length (all days), the initial phase (Days 1 to 5 ) and second half (Days 5 to 12) of the experiment. For further details see Fig. 1 


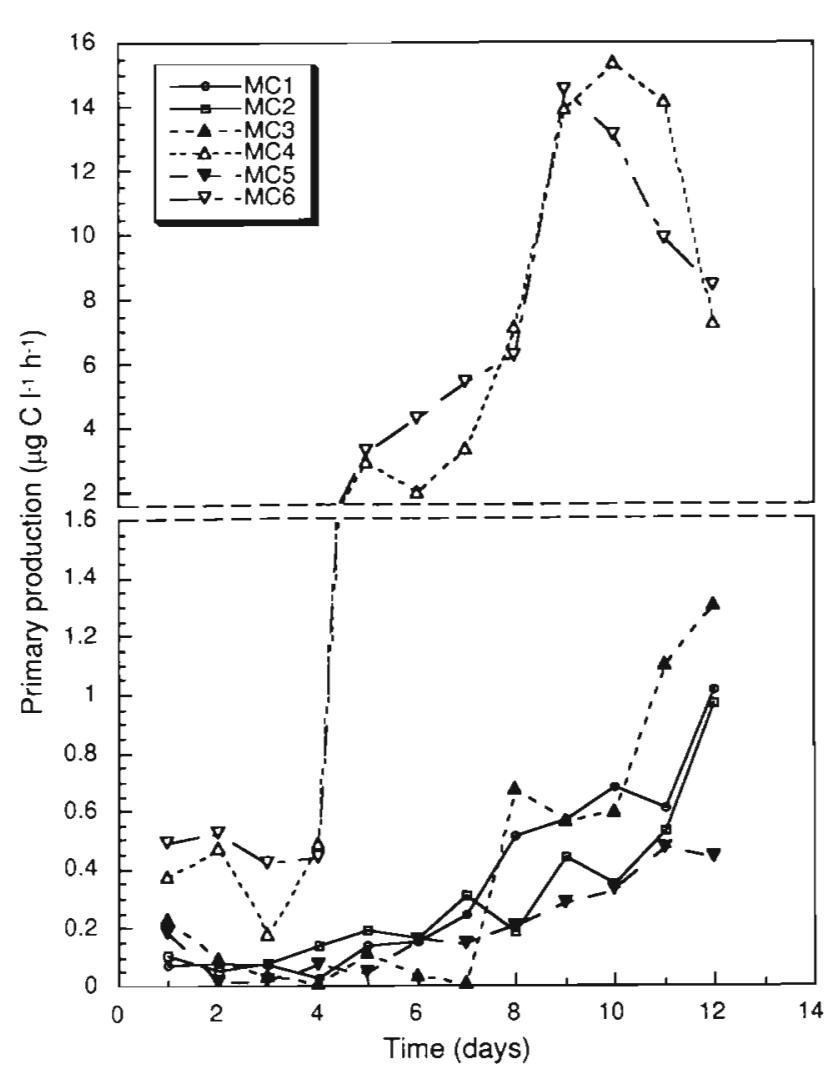

Fig. 5. Time course of primary production in Expt 1. For further details see Fig. 1

were highest in the ice biota treatments, then (Days 4 to 5) in the DOM set-ups and towards the end of the experiment (Days 8 to 10 ) in MC1 and MC2. This pattern, which exhibited large fluctuations, was more pronounced with respect to TTI (Fig. 8), where it showed clearly higher specific activities for MCs containing only planktonic bacteria during the second half of the experiment.

Initial bacterial production (calculated from TTI rates) was below $0.2 \mu \mathrm{g} \mathrm{Cl} \mathrm{Cl}^{-1} \mathrm{~h}^{-1}$ (data not shown) and about 10 times lower than primary production rates in all MCs. With time, bacterial production rates increased, respectively, to 2.8 and $2.4 \mu \mathrm{g} \mathrm{C} \mathrm{l}^{-1} \mathrm{~h}^{-1}$ in MC4 and MC6 with added sympagic biota. The addition of DOM (MC3 and MC5) stimulated bacterial growth even more to rates of up to $5.4 \mu \mathrm{g} \mathrm{C} \mathrm{l}^{-1} \mathrm{~h}^{-1}$. The ratio between bacterial and primary production changed markedly. After 3 to $4 \mathrm{~d}$ it was close to or even higher than 1 in all treatments, which is in accordance with zero or low initial growth rates for algae compared to bacteria. At the end of the experiment primary production exceeded bacterial growth by a factor of 5 to 8 in MC4 and 6, was equal to bacterial production in $\mathrm{MC1}$ and $\mathrm{MC2}$ and was 3 to 10 times lower in the DOM MCs.
Microbial uptake and degradation of DOM. As was observed for TTI, maximum uptake rates of glucose $\left(V_{\text {max; }}\right.$ Fig. $7 \mathrm{C}$ ) increased instantly only in MC4 and MC6 (ice biota) but did not increase much after Day 4 At this time, bacteria in MC3 and MC5 (DOM) vigorously started to use glucose, reaching higher $V_{\max }$ values (up to $0.4 \mu \mathrm{g} \mathrm{C} \mathrm{l}^{-1} \mathrm{~h}^{-1}$ ) after Day 5 than in $\mathrm{MCs}$ with sympagic organisms. Only the development in MCs containing DOM was significantly different to the control ( $p=0.03)$. In MC1 and MC2, a minor but steady increase over time was detected.

Degradation of macromolecules by aminopeptidases was low in all treatments without addition of ice biota. Turnover rates (Fig. 9a) levelled around $5 \% \mathrm{~d}^{-1}$, and did not increase during the experiment. In contrast, bacteria in MCs with ice organisms showed an instant and steady increase in turnover rates $(p=0.008)$ and maximum potential hydrolysis velocity $(p=0.03)$, with maximum values of about $66 \% \mathrm{~d}^{-1}$ and $33 \mu \mathrm{g} \mathrm{Cl}^{-1} \mathrm{~h}^{-1}$, respectively (Fig. 9b). Specific activities (data not shown) in MC4 and MC6 were roughly twice as high as those of the control and indicated that aminopeptidase activity of bacteria originating from ice was higher than that of water column bacteria.
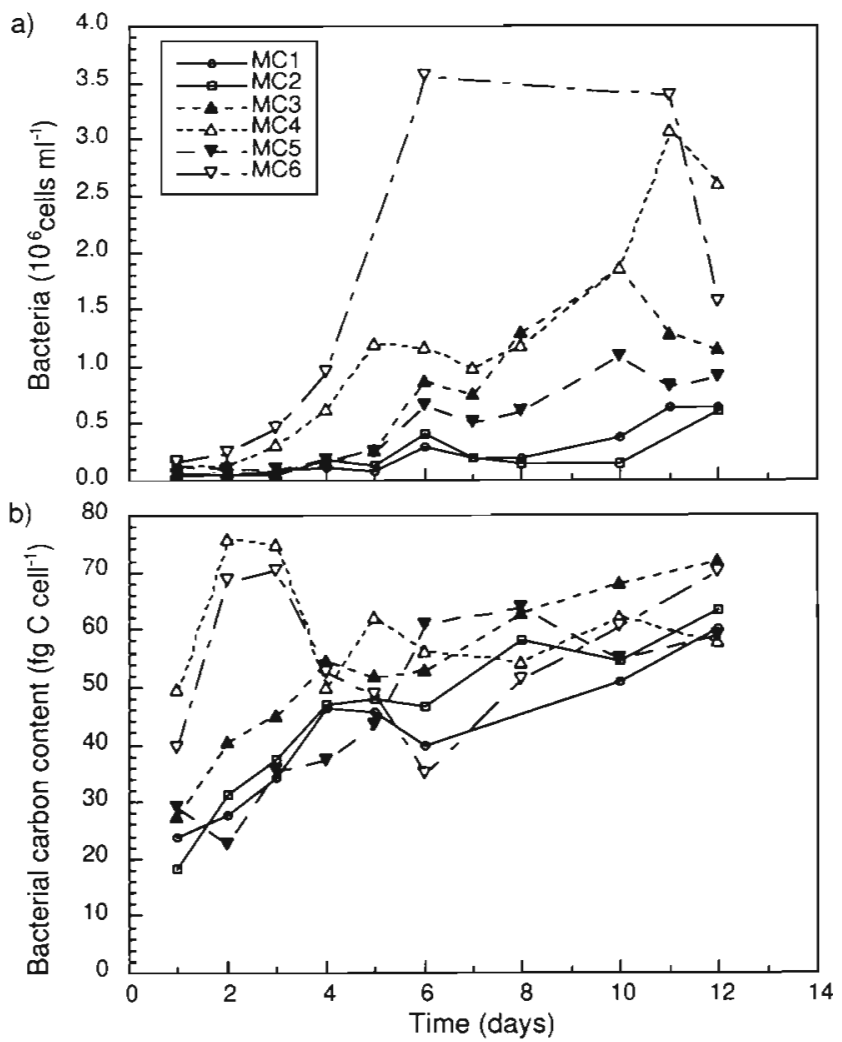

Fig. 6. Time course of (a) bacterial abundances and (b) mean bacterial cellular carbon content in Expt 1. For further details see Fig. 1 
Values of $K_{\mathrm{t}}+S_{\mathrm{n}}$ exhibited clear differences between the groups $\mathrm{MC1} / \mathrm{MC2}$, MC3/MC5 (DOM) and MC4/MC6 (ice biota) (Fig. 10c). The highest initial values (low substrate affinities) were found in MC1 and $\mathrm{MC2}$, while bacteria from ice biota MCs showed the highest affinities $(\mathrm{p}=0.018)$. In MC3 and MC5 $K_{\mathrm{t}}+S_{\mathrm{n}}$ values were lower than in the control $(\mathrm{p}=0.018$ and 0.06 , respectively), indicating an increased affinity in the DOM treatments since DOM addition must have enlarged the substrate pool $\left(S_{n}\right)$.
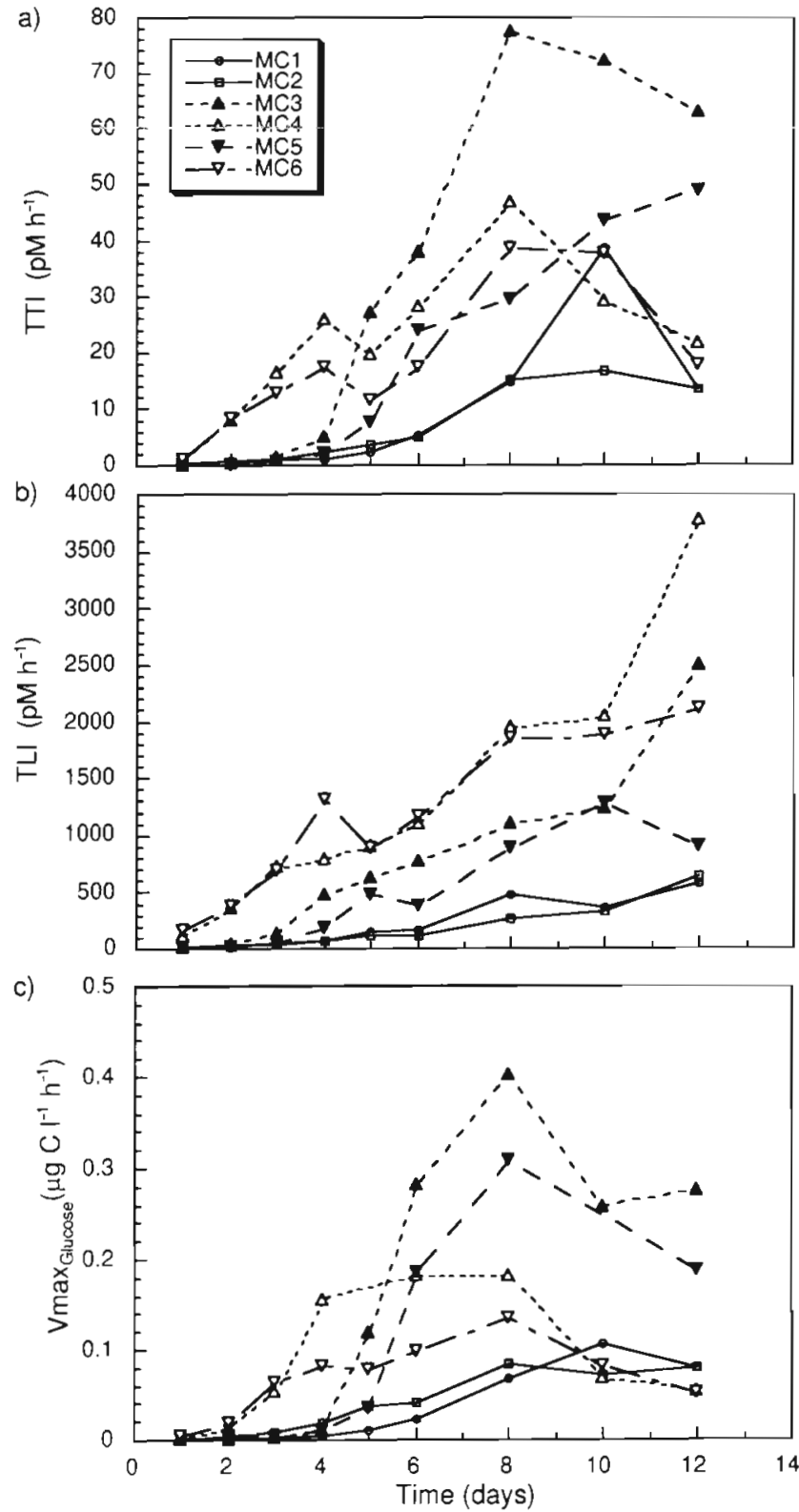

Fig. 7. Time course of (a) tritiated thymidine incorporation (TTI), (b) tritiated leucine incorporation (TLI) and (c) maximum glucose uptake rates $\left(V_{\text {maxam }}\right)$ in Expt 1. For further details see Fig. 1

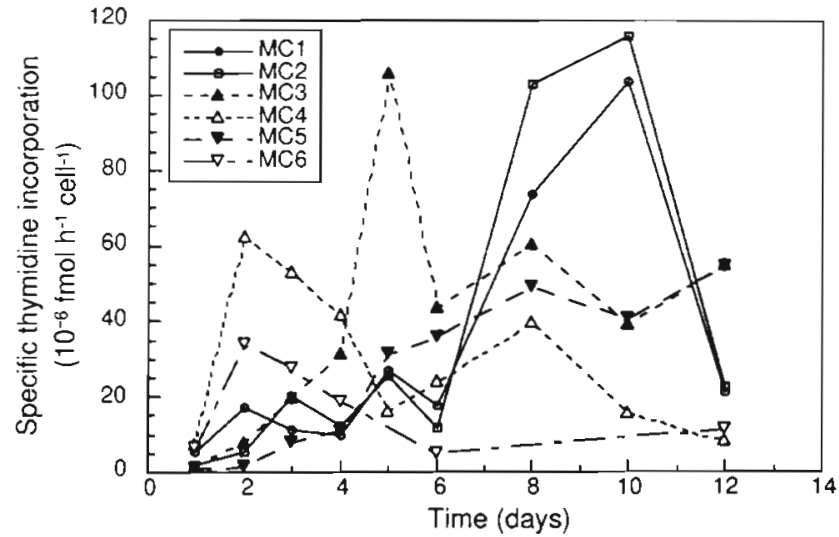

Fig. 8. Time course of specific thymidine incorporation rates in Expi î. Fur further deldiìs see Fiy. $\hat{i}$

Heterotrophic flagellate abundances. Initial abundances of heterotrophic flagellates (Fig. 10) were elevated in MC4 and MC6 due to the addition of the ice biota. Abundances ranged between 242 to 556 cells $\mathrm{ml}^{-1}$ for HPF and from 111 to 409 cells $\mathrm{ml}^{-1}$ for HNF. Data after Day 4 are scarce due to heavy clumping, high bacterial numbers and low HNF and HPF numbers. It was impossible to determine heterotrophic flagellate numbers properly because filters clogged before an adequate volume could be filtered.

Effects of stratification/improved illumination. All but 1 treatment simulated 'stratified' conditions by enclosing the investigated water. In general, stratifica-

Table 3. Effects of dissolved organic matter (DOM) inoculation and addition of sympagic organisms (Ice) relative to the control $(C=M C 1)$ in Expt 1. For 'DOM' and 'Ice' all data from MC3:MC1/MC5:MC1 and MC4:MC1/MC6:MC1 pairings were pooled, respectively, irrespective of differences in the temporal development. TBN $=$ total bacterial number; $T B B=$ total bacterial biomass; TTI $=$ tritiated thymidine incorporation; TLI = tritiated leucine incorporation; $V_{\max }=$ maximum uptake velocity of glucose; $\mathrm{PP}=$ primary production

\begin{tabular}{|llrrr|} 
& & & & \\
& & & & \\
& & & & \\
TBN & Mean & 2.41 & 6.35 & 2.21 \\
& Max & 6.40 & 11.96 & 5.38 \\
TBB & Mean & 2.73 & 6.81 & 2.49 \\
& Max & 6.60 & 12.84 & 9.14 \\
TTI & Mean & 3.10 & 7.50 & 2.42 \\
& Max & 11.78 & 24.50 & 51.64 \\
TLI & Mean & 2.74 & 9.01 & 3.29 \\
& Max & 7.42 & 20.36 & 23.80 \\
$V_{\text {max }}$ & Mean & 3.95 & 10.34 & 2.62 \\
Algae $<20 \mu \mathrm{m}$ & Max & 11.99 & 40.11 & 26.68 \\
& Mean & 0.69 & 2.93 & 4.24 \\
Algae $>20 \mu \mathrm{m}$ & Max & 1.51 & 9.12 & 32.22 \\
& Mean & 1.48 & 21.01 & 14.13 \\
PP & Max & 3.29 & 31.14 & 51.69 \\
& Mean & 0.96 & 15.27 & 15.95 \\
& Max & 3.23 & 28.25 & 67.29 \\
\hline
\end{tabular}


tion of surface water improves light availability in this water layer. Therefore, the simulation of 'mixing' conditions or shading by drifting ice floes in an otherwise stratified environment can be achieved by deteriorating light availability (MC2, Expt 1). Significant differences would be expected between the control (MC1) and the 'mixing' treatment (MC2) if stratification in combination with improved illumination were of major importance in the build-up of ice-edge blooms. However, in none of the investigated variables was there a significant difference in the 2 manipulations.

Effects of seeding versus DOM inoculation. The effects of the different treatments compared to the con-
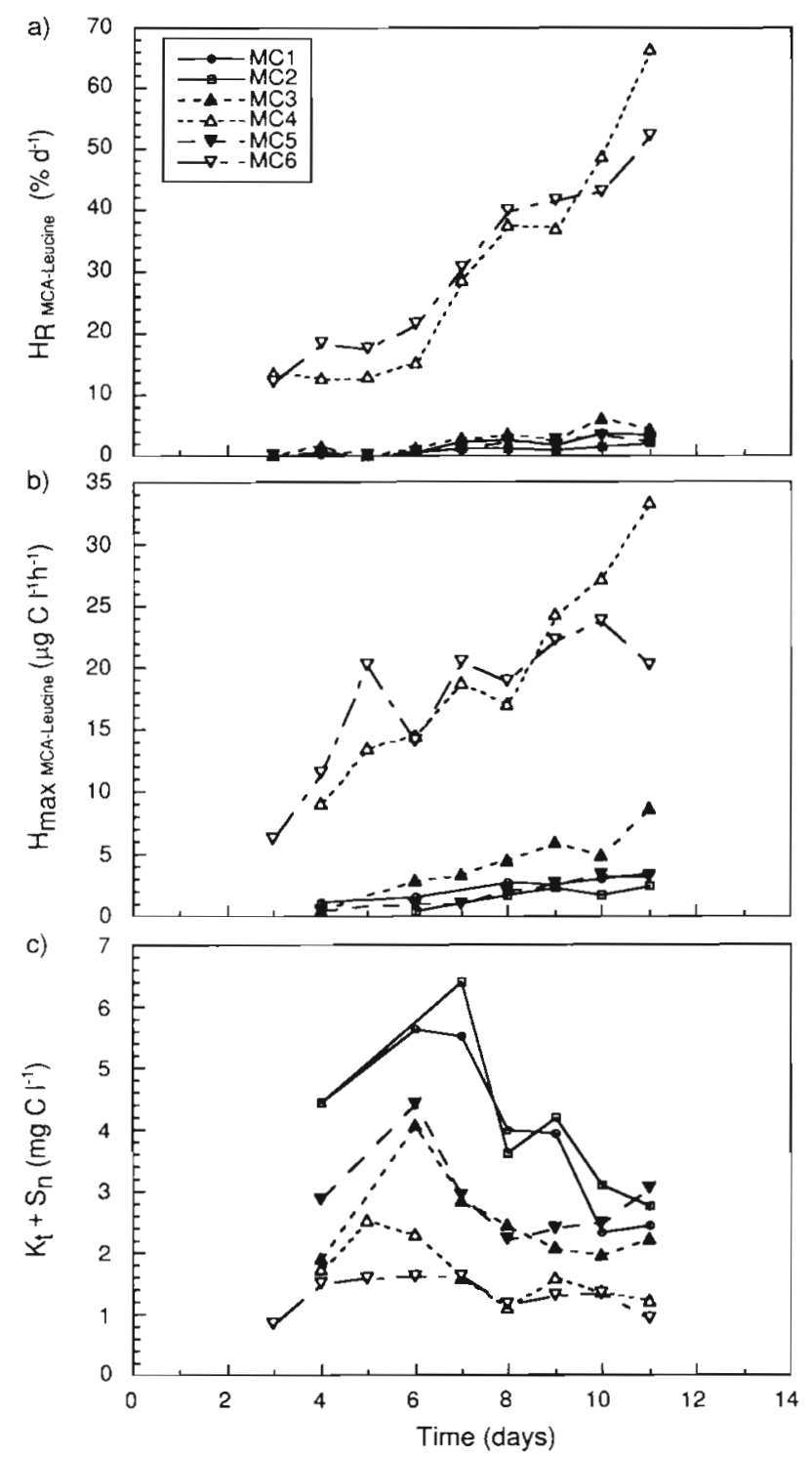

Fig. 9. Time course of (a) turnover rates $\left(H_{R}\right)$, (b) maximum hydrolysis velocity $\left(H_{\max }\right)$ and (c) the half saturation constant $\left(K_{l}\right)$ plus the natural substrate concentration $S_{n}$ of MCALeucine in Expt 1. For further details see Fig. 1
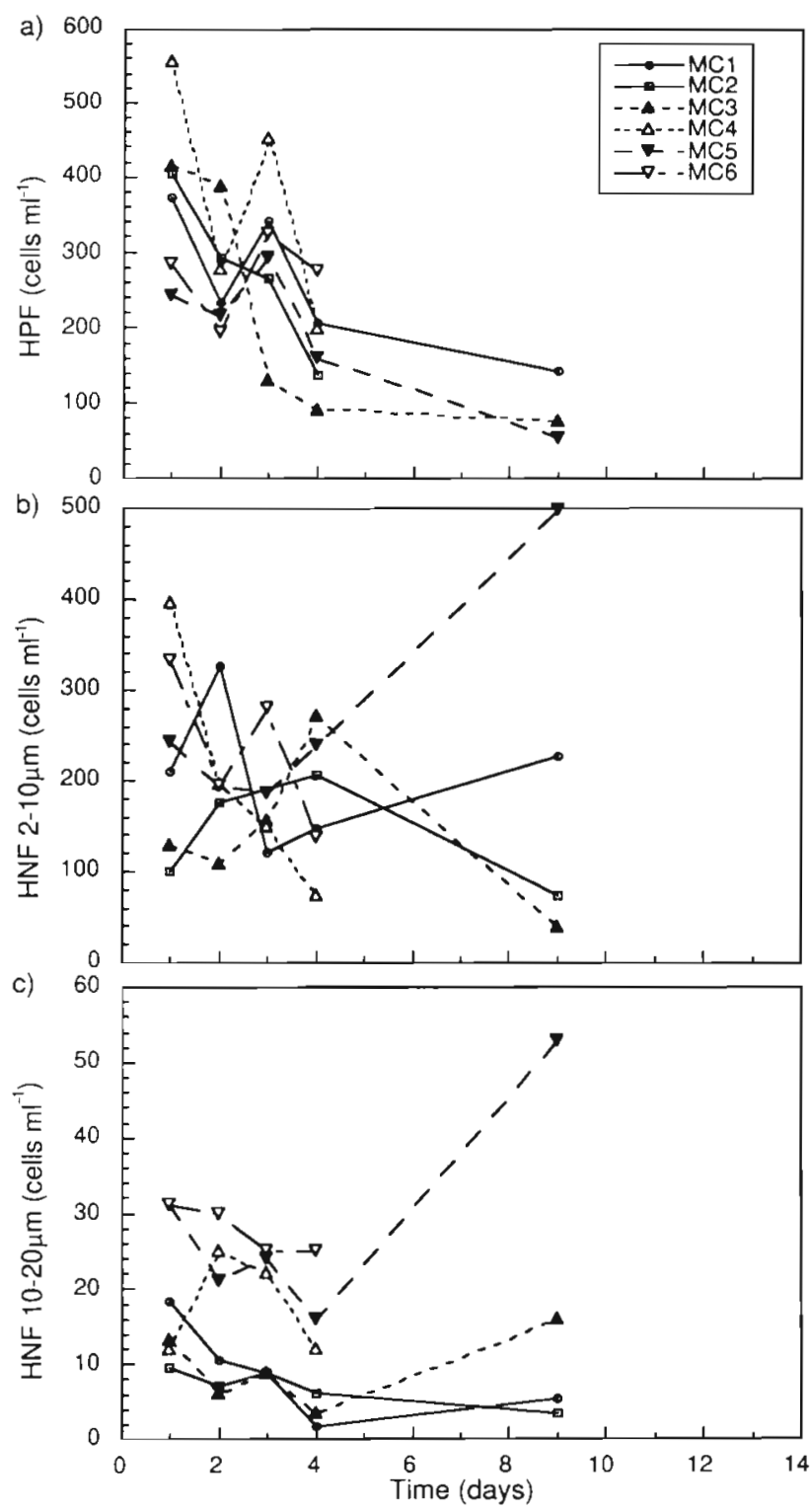

Fig. 10. Time course of heterotrophic flagellate abundances in Expt $1 . \mathrm{HPF}=$ heterotrophic picoflagellates, HNF $=$ heterotrophic nanoflagellates. For further details see Fig. 1

trol set-up, either for the mean or the maximal measured values for selected bacterial and phytoplankton variables, are listed in Table 3. Values from MC3 and MC5 as well as MC4 and MC6 were grouped to detect general outcomes of either DOM or ice biota addition. While DOM addition raised mean bacterial values by a factor of 2.4 to 4.0 , mean phytoplankton production was unaffected. In contrast, 'seeding' of ice biota had a pronounced influence on phytoplankton variables. The observed effect exceeded that of the DOM addition by a factor of up to 16 , whereas for means of bacterial values a factor between 2.2 and 3.3 was found. 


\section{Expt 2}

Nutrients. Initial nutrient concentrations in all treatments were comparable to the conditions in AWB water during Expt 1. In a manner similar to that of the first experimental series, nutrients decreased markedly only in MCs containing ice biota (MC7 and MC8),
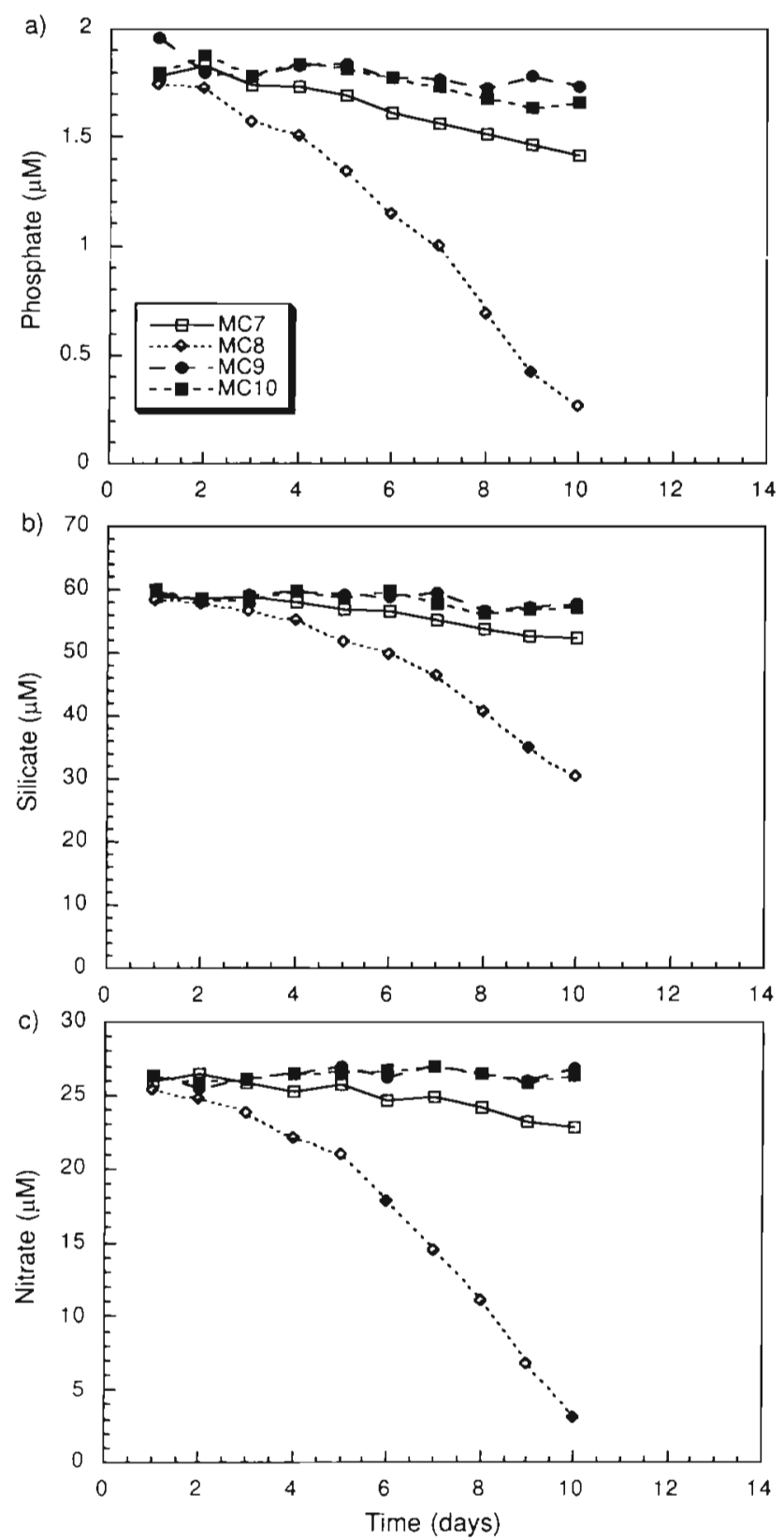

Fig. 11. Time course of nutrient concentrations in Expt 2. () $\mathrm{MC7}=200 \mu \mathrm{m}$ pre-screened AWB water, sympagic organisms and copepods; $(0) \mathrm{MC} 8=200 \mu \mathrm{m}$ pre-screened AWB water and sympagic organisms; ( $\mathrm{MC} 9=200 \mu \mathrm{m}$ pre-

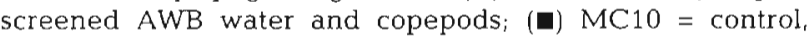
$200 \mu \mathrm{m}$ pre-screened AWB water
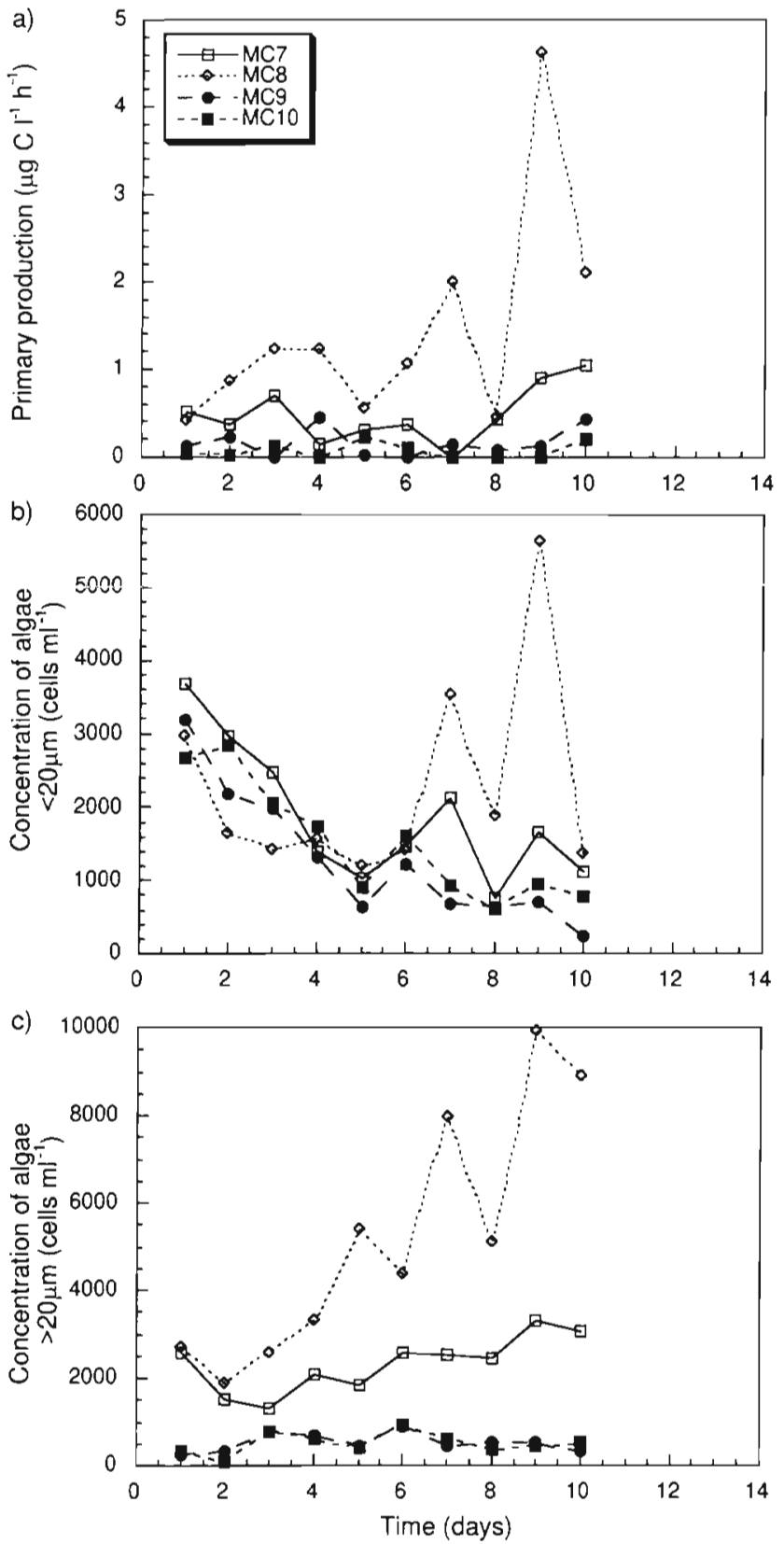

Fig. 12. Time course of (a) primary production, (b) autotrophic pico- and nanoplankton and (c) microalgal abundances in Expt 2. For further details see Fig. 11

which was diminished drastically in the presence of copepods (MC7; Fig. 11).

Phytoplankton abundances and growth. The time course of nutrients was again reflected by the development of microphytoplankton standing stocks (Fig. 12c). Microalgal abundances did not increase in MC9 and MC10 (without ice biota). In the other $2 \mathrm{MCs}$, which both contained ice organisms, abundances increased, but in the presence of copepods 

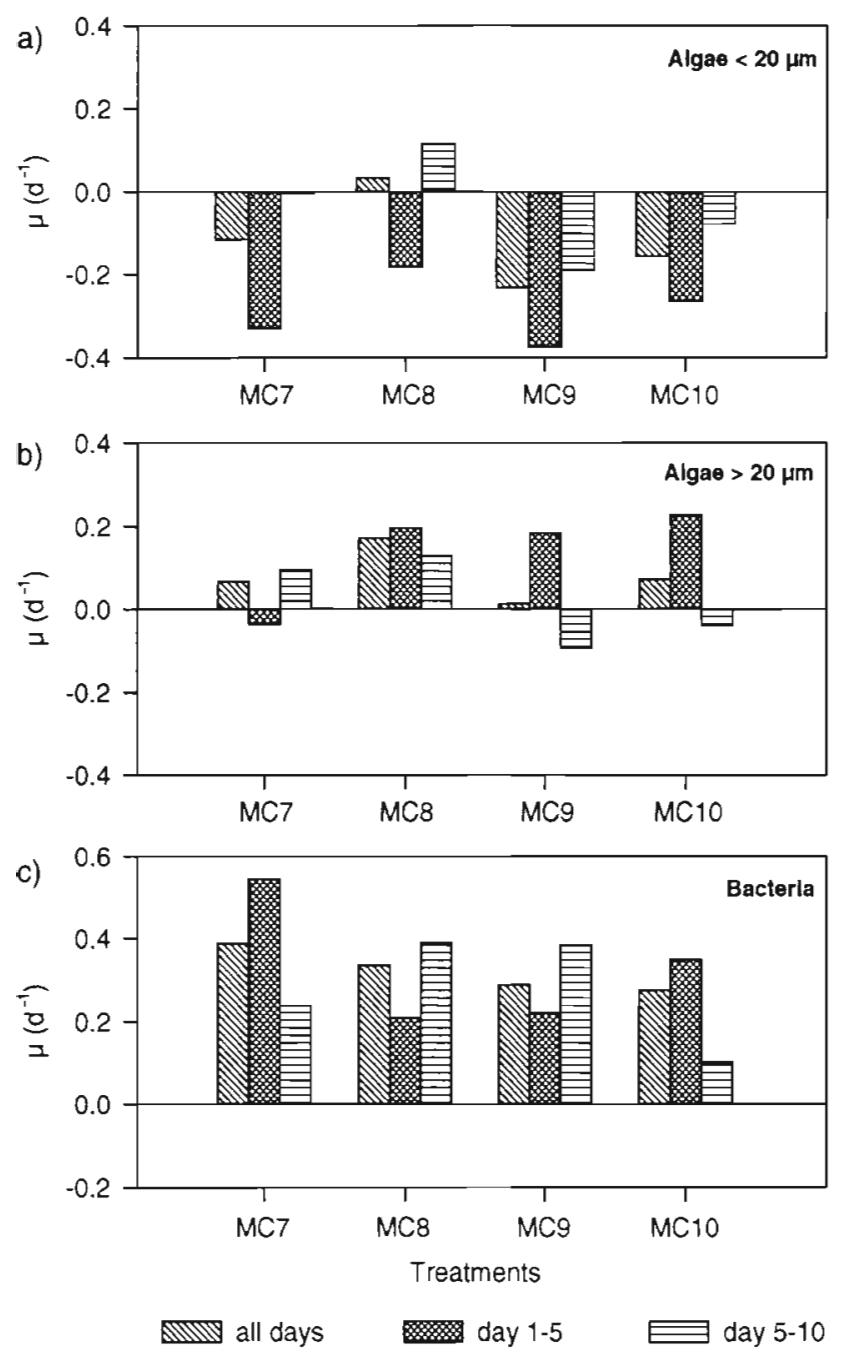

Fig. 13. Apparent growth rates of (a) algae $<20 \mu \mathrm{m}$, (b) algae $>20 \mu \mathrm{m}$ and (c) bacteria during Expt 2. Growth rates were calculated for the entire length (all days), the initial phase (Days 1 to 5 ) and second half (Days 5 to 10) of the experiment. For further details see Fig. 11

(MC7) the development was reduced and shifted to the second half of the experiment. This pattern was reproduced by the time course of primary production (Fig. 12a). APP and ANP (Fig. 12b) decreased initially in all MCs. During the second half of the experiment, numbers of algae $<20 \mu \mathrm{m}$ increased slightly in MC8 (ice biota without copepods) but did not recover in the other 3 MCs. Consequently, negative growth rates were observed in these treatments (Fig. 13a), although initial rates of -2.5 to $-3.7 \mathrm{~d}^{-1}$ slackened considerably during the second half of the experiment. Highest growth rates (up to $0.17 \mathrm{~d}^{-1}$ for the entire length of the experiment) were found for microphytoplankton (Fig. 13b). While the temporal development of primary production and microphytoplankton abundances in MC7 and MC8 was significantly different to the control $(p<0.009)$, changes in APP and ANP were not.

Bacterial abundances and growth. Bacterial numbers (Fig. 14a) increased in all MCs with growth rates of between 0.29 and $0.39 \mathrm{~d}^{-1}$ (Fig. 13c). Initial abundances in the ice biota set-ups were comparable to those of Expt 1 (MC7 vs MC4), but were higher by a factor of 2 to 3 in the control (MC10 vs MC1). Unlike Expt 1, bacterial development in the ice biota treatment without copepods was different to that in the control, only with $\mathrm{p}=0.06$. Cellular carbon content (Fig. 14b) also increased steadily, exhibiting a clear difference between set-ups. Values in MC9 and MC10 (without ice biota) were always lower $(p<0.01)$. The addition of copepods (MC7 and MC9) had no pronounced effect on bacterial numbers or activity (Fig. 15). Similar to the first experiment, ice biota addition resulted in a clear stimulation of TLI rates ( $p=0.012$ for MC7 and MC8 vs MC10) while it did not with respect to TTI.

In Expt 2 bacterial production exceeded primary production in all MCs after Day 5, with maximum val-
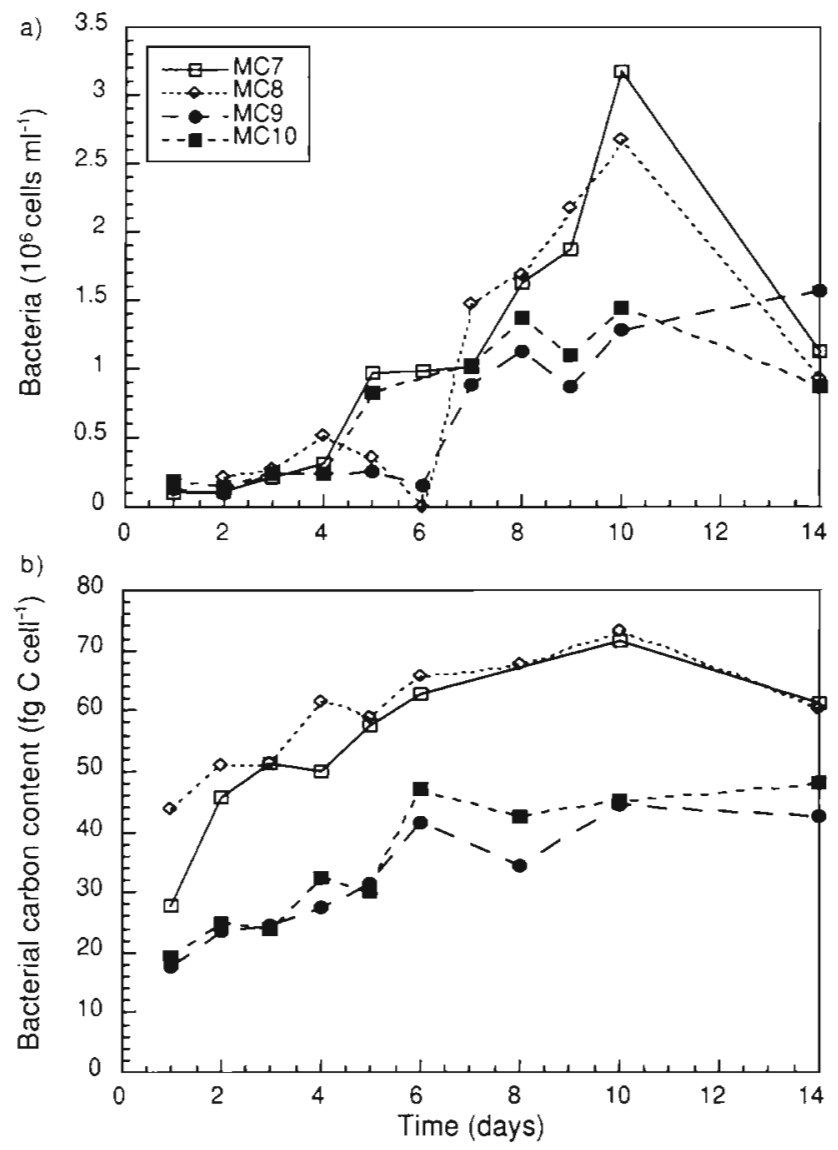

Fig. 14. Time course of (a) bacterial abundances and (b) mean bacterial cellular carbon content in Expt 2. For further details see Fig. 11 

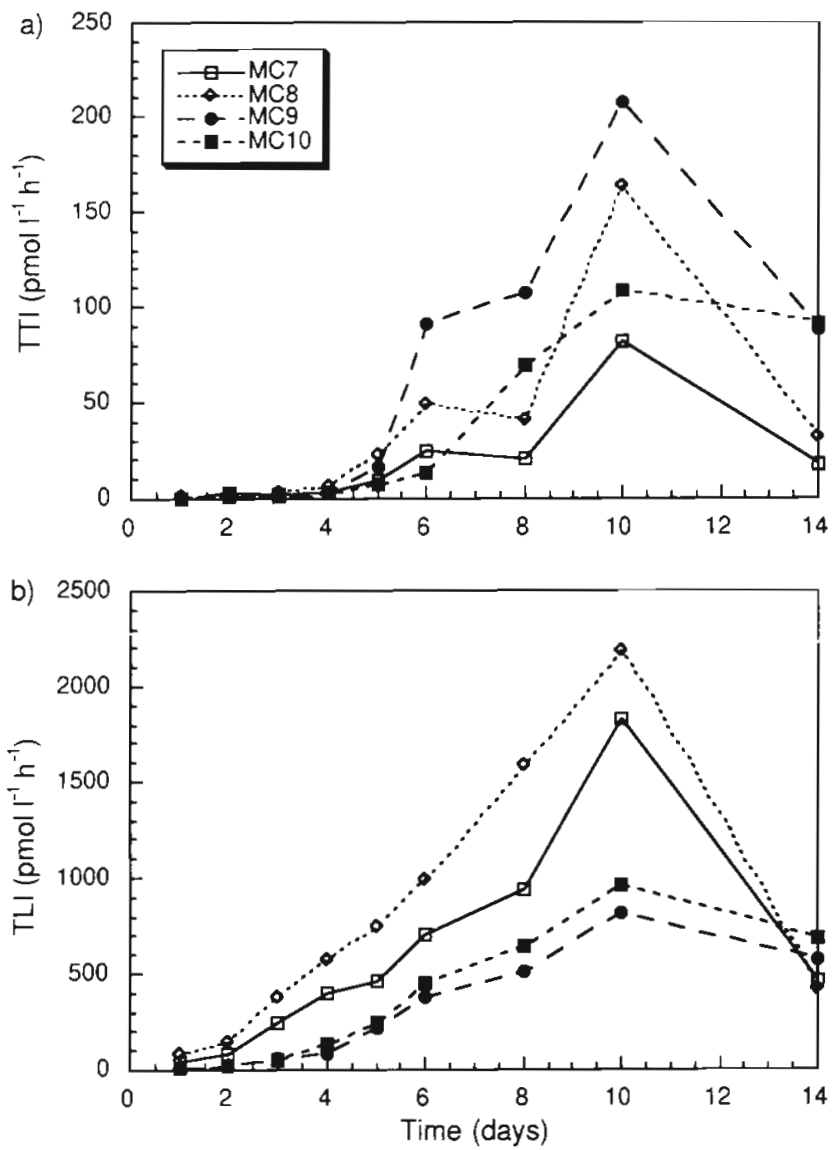

Fig. 15. Time course of (a) tritiated thymidine incorporation (TTI), (b) tritiated leucine incorporation (TLI) in Expt 2. For further details see Fig. 11

ues of 13.2 and $5.7 \mu \mathrm{C} \mathrm{l}^{-1} \mathrm{~h}^{-1}$ from TTI and TLI, respectively, occurring in $\mathrm{MC7}$ (ice biota without copepods).

Heterotrophic flagellate abundances and growth. Initial abundances of heterotrophic flagellates (Fig. 16) ranged between 310 (MC7) and 640 (MC8) cells $\mathrm{ml}^{-1}$. The abundance of heterotrophic protists decreased markedly in the control (MC10). While the abundance of HPF (Fig. 16a) also decreased in the other 3 treatments, we observed an increase in the HNF size fractions (Fig. 16b,c) of MC7 and MC8. Comparing $\mathrm{MC7}$ and $\mathrm{MC8}$, growth was significantly delayed in the presence of copepods (MC7). Initially HNF 2 to $10 \mu \mathrm{m}$ exhibited negative growth rates in $\mathrm{MCs}$ containing the sympagic community while during the second half of the experiment their growth rates equalled (MC8) or even exceeded (MC7) those of HNF 10 to $20 \mu \mathrm{m}$ (Fig. 17). Observed changes for HNF compared to the control were significant with $p<0.02$ except for HNF 2 to $10 \mu \mathrm{m}$ in MC8, although the development follows a clear and different pattern.
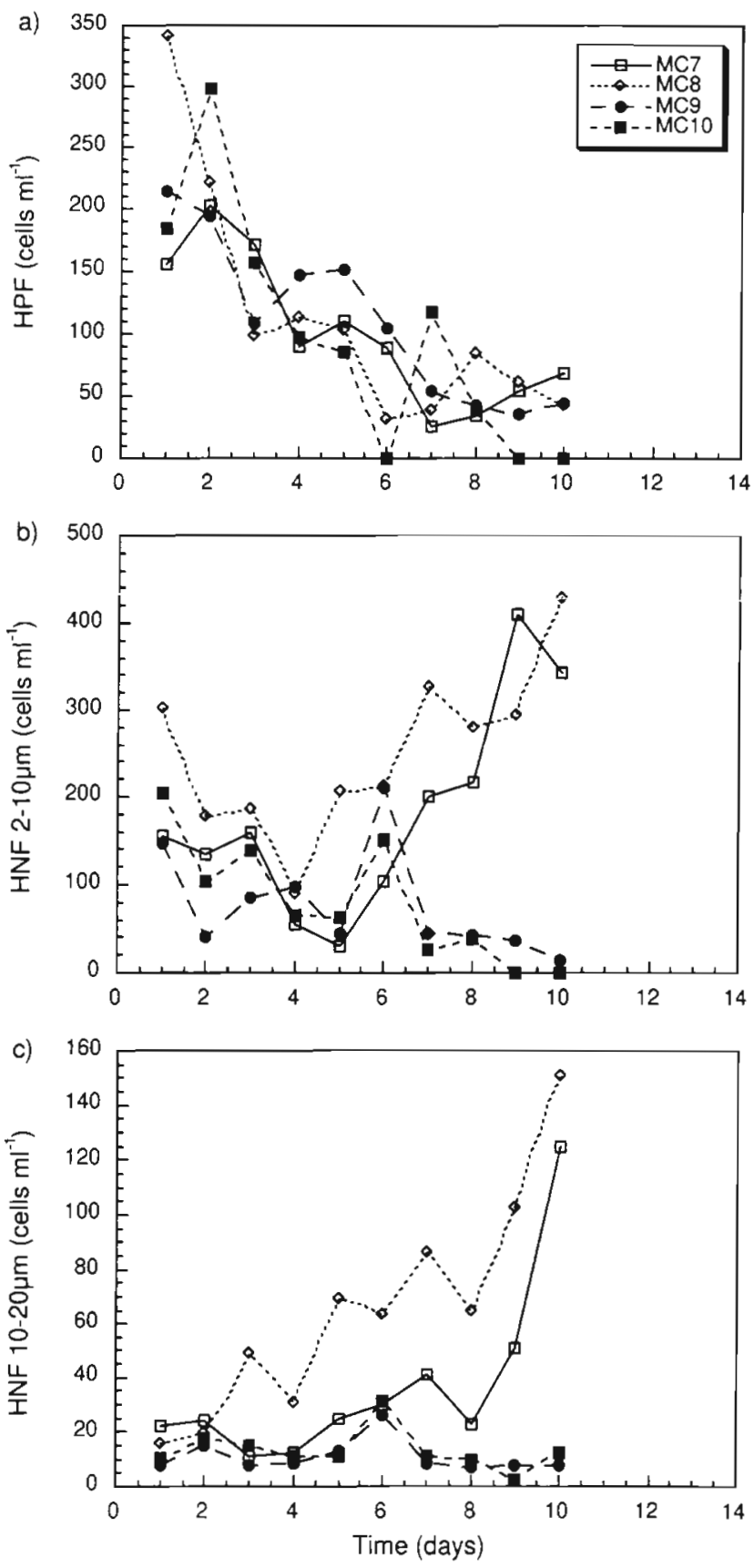

Fig. 16. Time course of heterotrophic flagellate abundances in Expt 2. HPF = heterotrophic picoflagellates, HNF = heterotrophic nanoflagellates. For further details see Fig. 11

\section{DISCUSSION}

Enclosures enable the investigation of plankton communities in a controlled system with respect to trophodynamic relationships and processes within the community, something which is usually impossible in the case of natural ecosystems (Kuparinen \& Bjørnsen 
1992). The microcosm experiments performed in this study were used as a tool to investigate the effects of ice melt on the microbial food web. The simulations comprised the main responsible factors for bloom development at the ice edge known so far, i.e. enhanced illumination, increased water column stability, introduction of dissolved and particulate (living and dead) sympagic organic matter into the pelagic system. In this context, it is worthwhile emphasizing that our experiments separated the effects of 'seeding' and 'DOM inoculation' during ice melt. The first experimental series focused on factors possibly inducing a bloom. The second series addressed sedimentation of microalgae and grazing by mesozooplankton, i.e. its possible top-down control for microalgal growth and
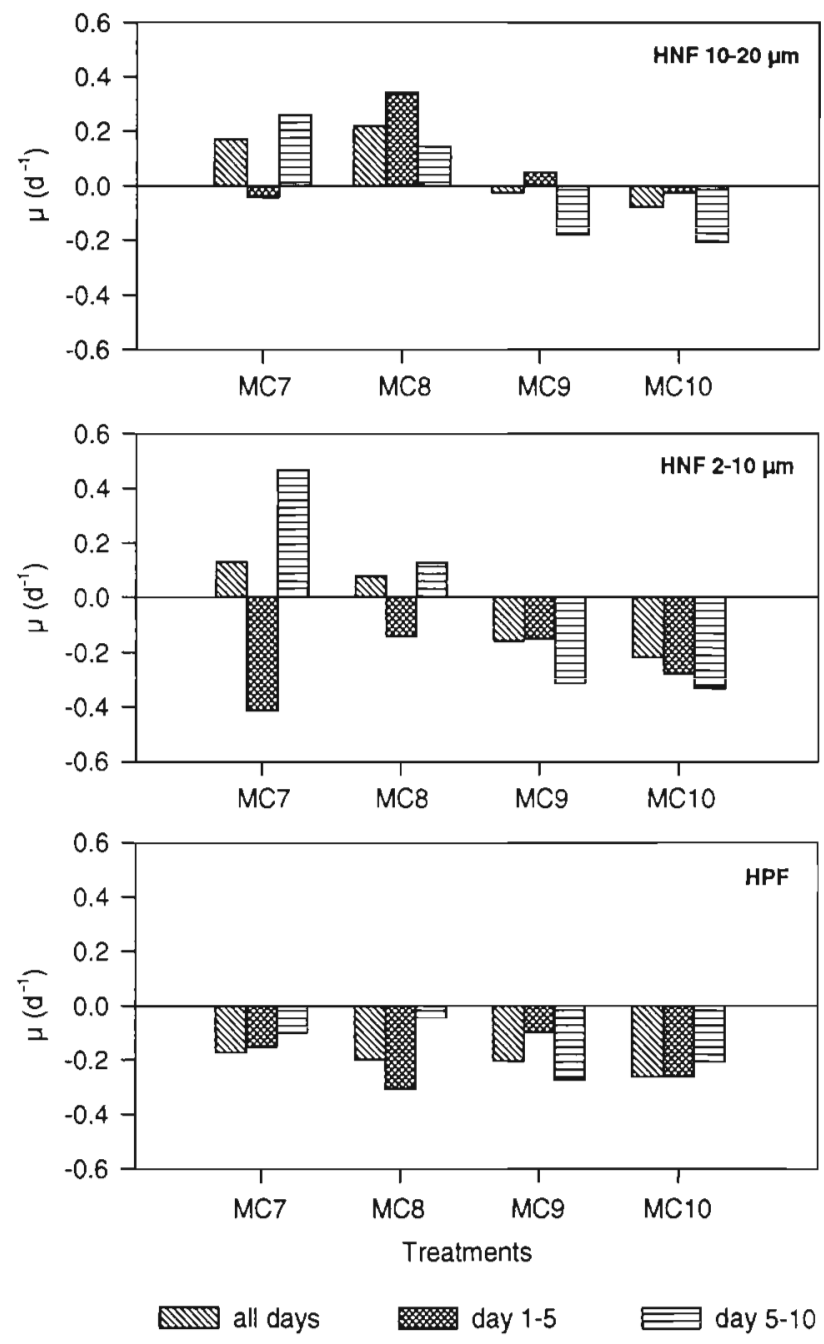

Fig. 17. Apparent growth rates of heterotrophic flagellates in 3 different size classes during Expt 2. HPF $=$ heterotrophic picoflagellates, HNF = heterotrophic nanoflagellates. Growth rates were calculated for the entire length (all days), the initial phase (Days 1 to 5) and second half (Days 5 to 10) of the experiment. For further details see Fig. 11 the following consequences for the other trophic levels, i.e. general changes of mass and energy transfer within the microbial food web.

\section{Experimental design}

The experimental design was chosen to be sufficient for a reaction of the mixed microbial community within the available time span. We are well aware that the addition of ice biota or prefiltered melted brown ice did not follow any type of in situ dilution. While the addition of ice biota did not alter the salinity in the treatments, since the dialysis bags were flushed with surface water, this cannot be excluded for the addition of prefiltered melted ice (DOM). The salinity of melted Antarctic ice normally ranges between 5 to 10 (Helmke \& Weyland 1995), and its addition reduced the salinity of the ACC or AWB waters by a maximum of $10 \%$ of the initial value. Although alterations in salinity have a pronounced influence on the activity of autotrophs (Arrigo \& Sullivan 1992), while heterotrophs show less response to variable salinity (Kottmeier \& Sullivan 1988), the final salinities (30 to 34 ) in the experimental treatments were close to the optimal salinity for ice biota (Kottmeier \& Sullivan 1988) and virtually unchanged for the open water communities.

The addition of 1.5 to $1.7 \mathrm{l}$ of melted ice resulted in a dilution of the open water communities in the microcosms, e.g. in a possible reduction of grazing pressure (Landry 1993). This effect was not accounted for in the control MCs (MC1 and MC10) and MC2, which should have received the same amount of prefiltered seawater. Experimental studies during the expedition (Becquevort 1997) revealed that grazing on autotrophs was of significance only in AWB water. Bacterial growth was not controlled by bacterivory in both hydrographic domains (AWB and ACC). Thus, further lowering of grazing pressure by sample dilution probably had no effect on ACC microcosms while it could lead to an overestimation of phytoplankton net growth in diluted AWB waters (MC3, MC4).

The addition of $0.2 \mu \mathrm{m}$ filtrate of melted brown ice was addressed as DOM inoculation. Certainly this term is more than imprecise although the melted ice was certainly a source of DOM to the surface water (Kähler et al. 1997). Besides DOM, macro- and micronutrients were added. Iron concentrations were 2 to 100 times higher in the ice (up to $100 \mathrm{nM}$ ) than in the surrounding surface water (Löscher et al. 1997). Addition of melted sea ice could stimulate algal growth in high-nutrient low-chlorophyll regions like Antarctica (de Baar et al. 1997) by micronutrient addition.

In Expt 2 Calanoides acutus was added. This calanoid copepod is an abundant, strictly herbivorous spe- 
cies of the Southern Ocean (e.g. Huntley \& Escritor 1991. Hopkins et al. 1993) and hibernates at great depths, from which it ascends during spring (SchnackSchiel \& Hagen 1994). Though C. acutus was still virtually absent in open ACC and AWB waters at the time of investigation, its distribution followed the development of phytoplankton accumulation at the Polar Frontal Zone (Fransz \& Gonzalez 1997). It therefore seemed a suitable species to simulate grazing on a developing phytoplankton bloom in the microcosms.

\section{Initial conditions in the open water relevant to the experiments}

Nutrient concentrations at the beginning of the experiments well reflected those found for the open waters of the ACC and AWB. While nitrate, ammonium and phosphate were present at almost equal (and unlikely to be limiting) concentrations of ca 27, 0.4 and $1.8 \mathrm{mmol} \mathrm{l}^{-1}$, respectively (de Baar et al. 1997, Quéguiner et al. 1997), both water masses were distinguished by higher silicate concentrations in the AWB. Quéguiner et al. (1997) attributed this to input from melted ice in the AWB area, but we did not observe a further increase of silicate concentrations in the DOM manipulations (MC3 and MC5). In none of the ice set-ups were the initial nutrient concentrations higher than in the control. Melted ice was thus not a macronutrient source. Unlike other nutrients, nitrate concentrations did not change during the first $3 \mathrm{~d}$ in the MCs. In spite of high nitrate concentrations ammonia seemed to have been taken up preferentially as it was also observed from field studies by Rönner et al. (1983) and Koike et al. (1986).

The AWB waters used for the 2 experiments were not similar, as has been mentioned for e.g. bacterial abundances. Also, upon close inspection of the nutrient concentrations small differences can be detected. Storms, meandering fronts and the ice retreat itself will certainly disallow 'identical' samples. Sea ice and communities living within are highly variable with respect to abundances and metabolic rates (Spindler et al. 1990, Helmke \& Weyland 1995). Though similar trends were observed in the ice biota treatments in both experiments, the detected differences can clearly be addressed to a different history of the used ice and its sympagic community

At the ice edge in the AWB and ACC, autotrophic pico- and nanoplankton were dominant compared to microalgae (Jochem et al. 1995, Detmer \& Bathmann 1997). Although the ice edge retreated about $400 \mathrm{~km}$ southward by break-up and melting (Smetacek et al. 1997, Veth et al. 1997), no ice edge bloom occurred over the entire 2 mo study period (Jochem et al. 1995).
Since the retreating ice edge passed 2 frontal systems with strong eddy activity, the input of meltwater was termed chaotic by Veth et al. (1997).

Abundances of auto- and heterotrophic pico- and nanoplankton were low in both water masses (Becquevort 1997, Detmer \& Bathmann 1997, Lochte et al. 1997), indicating late winter/pre-bloom conditions. In the ACC region neither phytoplankton nor bacteria concentrations were limited by proto- and metazooplankton grazing activity but grazing impact on autotrophs was high in the open waters of the AWB (Becquevort 1997, Klaas 1997). In AWB waters bacterioplankton carbon demand was as low as $30 \%$ of primary production, whereas in ACC water an average of $66 \%$ was consumed (Lochte et al. 1997).

\section{Effect of potentially bloom-inducing factors on the microbial food web}

Stratification/enhanced illumination

Stratification is considered a key factor in the development of ice-edge blooms (Smith \& Nelson 1985 , Lancelot et al. 1993) but not representative of the heterogeneous environment at the transition zone between $\mathrm{ACC}$ and $\mathrm{AWB}$ waters, i.e. the ice-edge zone at $6^{\circ} \mathrm{W}$ (Comiso 1991, Veth et al. 1997). Nonetheless, the establishment of stratified conditions will not hinder the development of a bloom neither in nature nor in MCs but rather enhance it as will improved illumination.

There was a 10 -fold increase of phytoplankton abundances and production in the control MC during the course of Expt 1. It was, however, not large enough to be thought of as the development of a bloom. In the second experiment, where sedimented algae were not reintroduced by shaking of the $\mathrm{MCs}$ no increase in phytoplankton variables was observed in the control. In contrast, bacterial abundance and production in the control MCs of both experients showed a marked increase. Upon simulated stratification of the water column and sedimentation of larger phytoplankton, the microbial food web shifted to a dominance of bacterial processes since heterotrophic flagellates revealed negative growth rates (MC10). The development of the ratio between primary and bacterial production in the different treatments confirms that after stratification the microbial food web is initially dominated by bacteria even when sympagic organisms are added.

The data obtained from the in situ investigations in $\mathrm{ACC}$ and $\mathrm{AWB}$ waters support these findings. Although $\mathrm{ACC}$ waters exhibited a more stable water column in the upper $100 \mathrm{~m}$ than AWB waters (Veth et al. 
1997), Jochem et al. (1995) could not detect any relation between autotrophic activity and water column stability during the entire length of the cruise. However, coupling between stratification and heterotrophic activities could be assumed during late winter/early spring from the data presented by Lochte et al. (1997), who observed a higher bacterial carbon demand in relation to primary production in the more stratified ACC waters. A possible dominance of heterotrophic metabolism rates during late winter/early spring is in accordance with data of Rivkin et al. (1989) investigating microbial populations in McMurdo Sound, Antarctica. Moreover, in the low temperature range, bacterial production may be favoured in comparison to primary production (Kottmeier \& Sullivan 1987). This is in contrast to the findings of Pomeroy et al. (1991) from Arctic open waters, where decreasing or low temperatures resulted in a less efficient use of organic substrates by bacteria and thus in a dominance of phytoplankton compared to bacterial production. However, enhanced supply with organic substrates, as may occur during ice melt, can change this disparity. In this respect, Kottmeier \& Sullivan (1988) stated that at least with respect to sympagic populations the hypothesis of an uncoupling between both trophic levels in cold waters must be refuted.

Stratification alone did not induce bloom formation of autotrophs within the time scale of our experiments (MC1 and MC10) but nonetheless provoked a steady increase in most of the measured variables in both experiments. Differences between the 'stratification' and the 'mixing' treatment (MC1 vs MC2) were generally not significant. Therefore, improved illumination compared to the conditions below the ice was also found not to enhance phytoplankton growth. The investigated system obviously lacked other major factors for bloom formation of autotrophs besides stratification and shifts in the light regime. The development of a phytoplankton bloom at the Polar Frontal Zone during cruise ANT X/6 (Bathmann et al, 1997), however, confirms the stimulating influence of stratification plus iron addition (Löscher et al. 1997, van Leeuwe et al. 1997) in the build-up of blooms.

\section{Seeding/DOM inoculation}

Additions of ice biota resulted in rapid growth of pico-, nano- and microalgae. A seeding effect was observed by the initially higher abundances compared to the controls. The microalgae tended to form aggregates and to sediment rapidly as reported by Riebesell et al. (1991). Shaking during Expt 1 led to reintroduction of settled aggregates to the plankton environment and thus to an overestimation of planktonic activity.
Addition of melted ice (MC3 to MC6) positively influenced microalgal growth compared to the control. Stimulation might be due to (1) sample dilution, especially for samples from AWB waters (MC3, MC4), (2) addition of micronutrients (MC3 to MC6), (3) stimulation of heterotrophic processes, which in turn provide essential substances for autotrophs such as siderophores (MC3, MC5), and (4) reduced grazing pressure due to lower numbers of nanoheterotrophs (MC3, MC5).

Van Leeuwe et al. (1997) demonstrated that in ACC and AWB waters iron was not limiting. We thus assume that micronutrients, at least iron, were not responsible for enhanced algal growth. In sea ice, algal growth was restricted by $\mathrm{Fe}$ availability, but $\mathrm{Fe}$ levels in open water must have still been high enough to allow the development of a bloom in the ice biota MCs. Additionally, the indicated initial uptake of ammonia would save $\mathrm{Fe}$, since only nitrate assimilation requires extra iron. Reduced grazing pressure by sample dilution and a decrease in abundances of nanoheterotrophs are consequently responsible for elevated microalgal growths rates.

In the DOM treatments we observed a decrease of pico- and nanoalgae. These algal groups were initially the major primary producers in samples without ice biota addition and also grew strongly in the treatments with added sympagic organisms. Their decrease is reflected in the reduction of primary production rates in MC5 and the missing increase in MC3. Based on the available data set we did not find a possible explanation for this phenomenon. However, from Expt 2 it can be assumed that the grazing activity of specific HNF size classes was responsible.

Melting of sea ice also influenced the development of bacteria. Addition of ice biota resulted in a marked increase in bacterial growth rates in the MCs. High initial cell carbon contents, cell specific activities (TTI and TLI) and growth rates in these treatments imply that initially growth was restricted to ice bacteria. DOM inoculation also caused an increase in activities of the open water bacteria. Specific activities were comparable to those of ice bacteria within less than 1 wk of incubation. In the control (MC1) specific activities increased after an initial lag phase of $1 \mathrm{wk}$.

Dissolved substances released from the ice apparently serve as a pre-conditioner or starter for the ACC and AWB bacterioplankton. The drastic increase of $V_{\max }$ accompanied by low hydrolysis rates in the DOM treatments gives a hint about the nature of the active substances. (1) A large part of the DOM did not need to be degraded for uptake but was in the form of directly incorporable monomers (e.g. sugars, amino acids) and (2) additional dissolved degradable material lowered the turnover rate of the hydrolysable DOM pool. Actually, a reduction of cellular peptidase activity was 
observed, though substrate affinities increased, which may be a direct result of endproduct repression by amino acids. Extremely high amino acid concentrations in Arctic sea ice were reported by Pomeroy et al. (1990). The readily accessible and biologically degradable nature of DOM was found for Antarctic as well as Arctic sea ice (Thomas et al. 1995, Kähler et al. 1997) and considered responsible for enlarged cell volumes of sympagic bacteria compared to pelagic forms (Kottmeier \& Sullivan 1990). Within the DOM pool, the dissolved nitrogen compounds (DON) may be used faster than DOC and are more closely correlated to other biological parameters (Thomas et al. 1995).

$K_{1}+S_{n}$ values in the DOM treatments were markedly reduced compared to the control. Since DOM inoculaiion must have a aised $S_{n}$ it cañ be assumed that substrate affinity $\left(K_{t}\right)$ more or less equalled that of ice bacteria after some days. Ice bacteria exhibited an extremely high substrate affinity for hydrolysable peptides because differences observed between ice biota set-ups and control were based on virtually the same $S_{\mathrm{n}}$. Turnover rates of monomers and polymers by sea ice bacteria even high for temperate waters (Rheinheimer 1991) were also observed in 'old ice' of the Weddell Sea during winter (Helmke \& Weyland 1995). After ice melt, activity of the seeded bacteria can obviously be temporarily maintained at a high level, transposed to the given pelagic conditions and transferred into biomass accumulation.

Unfortunately, the impact of the pico- and nanosized grazers could not be investigated properly in Expt 1. Nonetheless, the increase in bacteria (MC3 to MC6) and in phytoplankton (MC4 and MC6) during the experiment indicates that nanoflagellates were not capable of controlling growth in these treatments. Upon ice biota addition, the former tight coupling between pico- and nano-sized algae and their grazers in AWB waters was suspended

In contrast, the response of HNF and HPF to addition of ice biota could be followed in MC8, Expt 2. Eventually, all auto- and heterotrophic microoganisms except HPF grew in MC8, but only APP, ANP, HPF and small HNF decreased initially, indicating a shift in prey preferences. HNF 10 to $20 \mu \mathrm{m}$ in size probably grazed on all groups, including some microalgae, since the algal growth pattern was not exponential and HNF are known to feed on particles that exceed their own size (Gaines \& Elbrächter 1987). The large HNF therefore withdrew food organisms for 2 to $10 \mu \mathrm{m}$ HNF while feeding on them. Investigating North Atlantic protoand mesozooplankton populations, Paffenhöfer (1998) hypothesized that in the absence of metazooplankton, protozooplankton control their own abundances by predation/cannibalism. At the time when autotrophs $<20 \mu \mathrm{m}$ and HPF were exhausted 2 to $10 \mu \mathrm{m}$ HNF grazing demand could be satisfied by bacteria which had grown up in the meantime. The flagellates were, however, not capable of fully controlling bacterial growth. At the same time, grazing pressure on algae $<20 \mu \mathrm{m}$ slackened, which enabled them to grow, although HNF numbers still increased.

\section{Effects of sedimentation and mesozooplankton grazing}

The establishment of sedimentation conditions in the MCs led to reduced algal growth in the control compared to the first experiment. While APP and ANP showed negative growths rates over the entire length of the experiment, microalgae did not This is surprising, since according to Stoke's law microalgae should settle faster out of the system. An explanation might be that (initially) the heterotrophic flagellates compensated reduced microalgal growth by grazing more efficiently on the smaller phytoplankton. Growth rates of bacteria appeared unaffected.

The addition of sympagic organisms into a sedimentation regime (MC8) resulted in positive growth rates of both algal size classes and into the development of an algal bloom. Maximum abundances were lower than in the first experiment (MC4). This reduction was more pronounced for microalgae and can be addressed to higher sedimentation rates of micro-compared to nano- and picoalgae.

The addition of Calanoides acutus had 3 major consequences: (1) APP and ANP concentrations decreased steadily, (2) microalgae did not grow markedly above their initial abundances and (3) the development of HNF 10 to $20 \mu \mathrm{m}$ was significantly delayed. No negative effect was observed for the development of bacterial numbers, which might explain the only low overall influence detected for 2 to $10 \mu \mathrm{m}$ HNF. Unlike bacteria, HPF abundances were driven towards a low threshold stock with and without copepods present. They were either preferrably grazed by HNF or lacked escape mechanisms, as has been observed for bacteria (Jürgens \& Güde 1994), and were probably not recovering due to longer generation times.

\section{Conclusion}

Our results allow a more detailed insight into the coupling within the microbial food web and the effects of external pressure (e.g top-down control) during ice melt than previously reported. They confirm that the growth of phytoplankton $<20 \mu \mathrm{m}$ is particularly effectively controlled by grazers and that bacteria are either the least influenced group or even profit from changes 
indicating a relief of bottom-up control. The latter fact especially favours nanoheterotrophs. In turn, their feeding behaviour shifts the size spectrum of phytoplankton from a dominance of nano- and pico-sized forms to microalgae. In general, our observations agree with findings about a higher invariance of bacterioplankton compared to phytoplankton in winter and during ice melt (e.g. Cota et al. 1990, Becquevort et al. 1992, Mordy et al. 1995). Surprising, however, is our observation that the precence of (herbivorous) mesozooplankton even intensifies these shifts in community composition.

From Expt 2 it became obvious that ice retreat under favourable hydrographic conditions per se has a lesser impact on phytoplankton accumulation than the presence of grazers such as copepods. An autotrophic bloom will develop only when copepod concentrations are low in the surface layer. If the melting ice provides either more ice biota or DOM, then diatom blooms or bacterial blooms could develop. The occurrence of either diatom or bacterial blooms upon brown ice addition was also reported by Kuosa et al. (1992). In the presence of herbivorous (or omnivorous) mesozooplankton at concentrations actually observed at the ice edge, bacterial blooms can also occur, but algal blooms are unlikely.

In the Atlantic land-remote sector of the Antarctic, grazers are abundant enough to control possible autotrophic bloom development upon seeding by ice algae, which explains the lack of blooms as viewed by remote-sensing in this area. In this respect the vernal plankton development is more similar to the North Pacific Ocean, where blooms are also absent (Frost 1991), than to the North Atlantic or the Weddell Sea.

Acknowledgements. We thank the captain and crew of the RV 'Polarstern' for their help during cruise ANT X/6. Peter Fritsche is gratefully acknowledged for measuring the nutrient concentrations. For helpful discussions and support we thank our colleagues on board. This work was funded by the Deutsche Forschungsgemeinschaft, contract number Jo $192 / 4-1$

\section{LITERATURE CITED}

Arrigo KR, Sullivan CW (1992) The influence of salinity and temperature covariation on the photophysiological characteristics of Antarctic sea ice microalgae. J Phycol 28 : $746-756$

Bathmann UV, Scharek R, Klaas C, Dubischar CD, Smetacek $\mathrm{V}$ (1997) Spring development of phytoplankton biomass and composition in the major water masses of the Atlantic sector of the Southern Ocean. Deep-Sea Res II 44:51-68

Becquevort S (1997) Nanoprotozooplankton in the Altlantic sector of the Southern Ocean during early spring: biomass and feeding activities. Deep-Sea Res II 44:355-374
Becquevort S, Mathot S, Lancelot C (1992) Interactions in the microbial community of the marginal ice zone of the northwestern Weddell Sea through size distribution analysis. Polar Biol 12:211-218

Bjørnsen PK, Kuparinen J (1991a) Growth and herbivory by heterotrophic dinoflagellates in the Southern Ocean, studied by microcosm experiments. Mar Biol 109:397-405

Bjernsen PK, Kuparinen J (1991b) Determination of bacterioplankton biomass, net production and growth efficiency in the Southern Ocean. Mar Ecol Prog Ser 71:185-194

Comiso JC (1991) Satellite remote sensing of polar oceans. J Mar Syst 2:395-434

Cota GF, Kottmeier ST, Robinson DH, Smith WO, Sullivan CW (1990) Bacterioplankton in the marginal ice zone of the Weddell Sea: biomass, production and metabolic activities during austral autumn. Deep-Sea Res 37: 1145-1167

de Baar HJW, van Leeuwe MA, Scharek R, Goeyens L, Bakker KMJ, Fritsche P (1997) Nutrient anomalies in Fragilariopsis kerguelensis blooms, iron deficiencies and the nitrate/phosphate ratio (A. C. Redfield) of the Antarctic Ocean. Deep-Sea Res II 44:229-260

Delucca R, McCracken MD (1977) Observations on interactions between naturally-collected bacteria and several species of algae. Hydrobiologia 55:71-75

Detmer AE, Bathmann UV (1997) Distribution patterns of autotrophic pico- and nanoplankton and their relative contribution to algal biomass during spring in the Atlantic sector of the Southern Ocean. Deep-Sea Res II 44:299-320

Fransz HG (1988) Vernal abundance, structure and development of epipelagic copepod populations of the eastern Weddell Sea (Antarctica). Polar Biol 9:107-114

Fransz HG, Gonzalez SR (1997) Latitudinal metazoan plankton zones in the Atlantic Circumpolar Current along $6^{\circ} \mathrm{W}$ during Austral spring 1992. Deep-Sea Res II 44:395-414

Frost BW (1991) The role of grazing in nutrient-rich areas of the open sea. Limnol Oceanogr 36:1616-1630

Fuhrman JA, Azam F (1982) Thymidine incorporation as a measure of heterotrophic bacterioplankton production in marine surface waters: evaluation and field results. Mar Biol 66:109-120

Gåines G, Elbrächter $M$ (1987) Heterotrophic nutrition. In Taylor FJR (ed) The biology of dinoflagellates. Blackwell, Oxford, p 103-122

Garrison DL, Buck KR (1986) Organism losses during ice melting: a serious bias in sea ice community studies. Polar Biol 6:237-239

Garrison DL, Buck KR (1989) Protozooplankton in the Weddell Sea, Antartica: abundance and distribution in the ice edge zone. Polar Biol 9:341-351

Garrison DL, Gowing MM (1992) Protozooplankton. In: Friedmann EI (ed) Antarctic microbiology. Wiley-Liss, New York, p 123-165

Garrison DL, Sullivan CW, Ackley SF (1986) Sea ice microbial communities in Antartica. BioScience 36:243-250

Garrison DL, Buck KR, Fryxell GA (1987) Sea ice algal communities in Antarctica: species assemblages in pack ice and ice edge planktonic communities. J Phycol 23: $564-572$

Garrison DL, Buck KR, Gowing MM (1993) Winter plankton assemblage in the ice edge zone of the Weddell and Scotia Seas: composition, biomass and spatial distribution. Deep-Sea Res 40:311-338

Gocke K (1975) Studies on short-term variations of heterotrophic activity in the Kiel Fjord. Mar Biol 33:39-55

Grasshoff K, Erhard M, Kremling K (1983) Methods in sea water analysis, 2nd edn. Verlag Chemie, Weinheim 
Grossmann S, Gleitz M (1993) Microbial response to experimental sea-ice formation: implications for the establishment of Antarctic sea-ice communities. J Exp Mar Biol Ecol 1.73:273-289

Haas LW (1982) Improved epifluorescence microscopy for observing planktonic organisms. Ann Inst Oceanogr Paris 58:261-266

Helmke E, Weyland H (1995) Bacteria in sea ice and underlying water of the eastern Weddell Sea in midwinter. Mar Ecol Prog Ser 117:269-287

Hewes CD, Holm-Hansen O, Sakshaug E (1985) Alternate carbon pathways at lower trophic levels in the Antarctic food web. In: Siegfried ER, Condy PR, Laws RM (eds) Antarctic nutrient cycles and food webs. Springer, Berlin, p 227-283

Hopkins TL, Ainley DG, Torres JJ, Langraft TM (1993) Trophic structure in open waters of the marginal ice zone in the Scotia-Weddell confluence region during spring (1983). Polar Biol 13:389 397

Hoppe HG (1993) Use of fluorogenic model substrates for extracellular enzyme activity (EEA) measurement of bacteria. In: Kemp PF, Sherr BF, Sherr EB, Cole JJ (eds) Handbook of methods in aquatic microbial ecology. Lewis Publishers, London, p 423-431

Huntley ME, Escritor F (1991) Dynamics of Calanoides acutus (Copepoda: Calanoida) in Antarctic coastal waters. J Mar Res 45:911-945

Jochem FJ, Mathot S, Quéguiner B (1995) Size-fractionated primary production in the open Southern Ocean in austral spring. Polar Biol 15:381-392

Jürgens K, Güde H (1994) The potential importance of grazing-resistant bacteria in planktonic systems. Mar Ecol Prog Ser 112:169-188

Kähler P, Bjørnsen PK, Lochte K, Antia A (1997) Dissolved organic matter and its utilization by bacteria during spring in the Southern Ocean. Deep-Sea Res II 44:341-353

Kirchman DL, K'nees E, Hodson R (1985) Leucine incorporation and its potential as a measure of protein synthesis by bacteria in natural aquatic systems. Appl Environ Microbiol 49:599-607

Kivi K, Kuosa H (1994) Late winter microbial communities in the western Weddell Sea (Antartica). Polar Biol 14 389-399

Klaas C (1997) Microprotozooplankton distribution and their potential grazing impact in the Atlantic Circumpolar Current. Deep-Sea Res II 44:375-394

Knox GA (1990) Primary production and consumption in McMurdo Sound, Antarctica. In: Kerry KR, Hempel G (eds) Antarctic ecosystems. Ecological change and conservation. Springer, Heidelberg, p 115-128

Koike I, Holm-Hansen O, Biggs DC (1986) Inorganic nitrogen metabolism by antarctic phytoplankton with special reference to ammonium cycling. Mar Ecol Prog Ser 30:105-116

Kottmeier ST, Sullivan CW (1987) Late winter primary production and bacterial production in the sea ice and seawater west of the Antarctic Peninsula. Mar Ecol Prog Ser 36: $287-298$

Kottmeier ST, Sullivan CW (1988) Sea ice microbial communities (SIMCO) 9. Effects of temperature and salinity on rates of metabolism and growth of autotrophs and heterotrophs. Polar Biol 8:293-304

Kottmeier ST, Sullivan CW (1990) Bacterial biomass and production in pack ice of Antarctic marginal ice edge zones. Deep-Sea Res 37:1311-1330

Kuosa H, Normann B, Kiwi K, Brandini F (1992) Effects of Antarctic sea ice biota on seeding as studied in aquarium experiments. Polar Biol 12:333-339
Kuparinen J, Bjørnsen PK (1992) Spatial distribution of bacterioplankton production across the Weddell-Scotia confluence during early austral summer 1988-1989. Polar Biol 12:197-204

Lancelot C, Mathot S, Veth C, de Baar HJW (1993) On the factors controlling phytoplankton ice edge blooms in the marginal ice zone of the northwestern Weddell Sea during ice retreat 1988. Polar Biol 13:377-387

Landry MR (1993) Estimating rates of growth and grazing mortality of phytoplankton by the dilution method. In: Kemp PF, Sherr BF, Sherr EB, Cole JJ (eds) Handbook of methods in aquatic microbial ecology. Lewis Publishers, London, p 715-722

Laubscher RK, Perissinotto R, McQuaid CD (1993) Phytoplankton production and biomass at frontal zones in the Atlantic sector of the Southern Ocean. Polar Biol 13: $471-481$

Legendre L, Demers S, Yentsch CM, Yentsch CS (1983) The ${ }^{14} \mathrm{C}$ method: patterns of dark $\mathrm{CO}_{2}$ fixation and DCMU correction to replace the dark bottle. Limnol Oceanogr 28: $996-1003$

Lochte K, Bjørnsen PK, Giesenhagen HC, Weber A (1997) Bacterial standing stock and production and their relation to phytoplankton in the Southern Ocean. Deep-Sea Res II 44:321-340

Löscher BM, de Baar HJW, de Jong JTM, Veth C, Dehairs F (1997) The distribution of $\mathrm{Fe}$ in the Antarctic Circumpolar Current. Deep-Sea Res II 44:143-188

Martin JH, Gordon RM, Fitzwater SE (1990) Iron in Antarctic waters. Nature 345:156-158

Mathot S, Bequevort S, Lancelot C (1991) Microbial communities from the sea ice and adjacent water column at the time of ice melting in the northwestern part of the Weddell Sea. Polar Res 10(1):267-275

Mordy CW, Penny DM, Sullivan CW (1995) Spatial distribution of bacterioplankton biomass and production in the marginal ice-edge zone of the Weddell-Scotia Sea during austral winter. Mar Ecol Prog Ser 122:9-19

Paffenhöfer GA (1998) Heterotrophic protozoa and small metazoa: feeding rates and prey-consumer interactions. J Plankton Res 20:121-133

Pomeroy LR, Macko SA, Ostrom PH, Dunphy J (1990) The microbial food web in Arctic seawater: concentration of dissolved free amino acids and bacterial abundance and activity in the Arctic Ocean and in Resolute Passage. Mar Ecol Prog Ser 61:31-40

Pomeroy LR, Wiebe WJ, Deibel D, Thompson RJ, Rowe GT, Pakulski JD (1991) Bacterial responses to temperature and substrate concentration during the Newfoundland spring bloom. Mar Ecol Prog Ser 75:143-159

Porter KG, Feig YS (1980) The use of DAPI for identifying and counting bacteria. Limnol Oceanogr 25:105-110

Quéguiner B, Tréguer P, Peeken I, Scharek R (1997) Biogeochemical dynamics and the silicon cycle in the Atlantic sector of the Southern Ocean during austral spring 1992. Deep-Sea Res II 44:69-90

Rheinheimer G (1991) Mikrobiologie der Gewässer, Gustav Fischer, Stuttgart

Riebesell U, Schloss I, Smetacek V (1991) Aggregation of algae released from melting sea ice: implications for seeding and sedimentation. Polar Biol 11:239-248

Rivkin RB, Putt M, Alexander SP, Meritt D, Gaudet L (1989) Biomass and production in polar planktonic and sea ice communities: a comparative study. Mar Biol 101:273-283

Rönner U, Sörensen $F_{1}$ Holm-Hansen O (1983) Nitrogen assimilation by phytoplankton in the Scotia Sea. Polar Biol $2: 137-147$ 
Scharek R (1991) Die Entwicklung des Phytoplanktons im östlichen Weddellmeer (Antarktis) beim Übergang vom Spätwinter zum Frühjahr. Ber Polarforsch 94:1-191

Schnack-Schiel SB, Hagen W (1994) Life cycle strategies and seasonal variations in distribution and population structure of four dominant calanoid copepod species in the eastern Weddell Sea, Antarctica. J Plankton Res 16:1543-1566

Simon M, Azam F (1989) Protein content and protein synthesis rates of planktonic bacteria. Mar Ecol Prog Ser 51 : $201-213$

Smetacek V, de Baar HJW, Bathmann UV, Lochte K, Rutgers van der Loeff MM (1997) Ecology and biochemistry of the Antarctic Circumpolar Current during austral spring: a summary of Southern JGOFS cruise ANT X/6 of R.V Polarstern. Deep-Sea Res II 44:1-22

Smith WO, Nelson DM (1985) Phytoplankton bloom produced by a receding ice edge in the Ross Sea: spatial coherence with the density field. Science 227:163-166

Spindler M, Dieckmann GS, Lange MA (1990) Seasonal and geographic variations in sea ice community structure of the Weddell Sea, Antarctica. In: Kerry KR, Hempel G (eds) Ecological change and conservation. Springer, Berlin, p 125-135

Editorial responsibility: John Dolan,

Edgewater, Maryland, USA
Steemann Nielsen E (1952) The use of radioactive carbon $\left({ }^{14} \mathrm{C}\right)$ for measuring organic production in the sea. J Cons Int Explor Mer 18:117-140

Thomas DN, Lara RJ, Eicken H, Kattner G, Skoog A (1995) Dissolved organic matter in Arctic multi-year ice during winter: major components and relationship to ice characteristics. Polar Biol 15:477-483

van Leeuwe MA, Scharek R, de Baar HJW, de Jong JTM, Goeyens L (1997) Iron enrichment experiments in the Southern Ocean: physiological responses of plankton communities. Deep-Sea Res II 44:189-208

Venrick EL (1978) How many cells to count? In: Sournia A (ed) Phytoplankton manual. Monographs of oceanographic methodology, Vol 6. UNESCO, Paris, p 167-180

Veth C, Peeken I, Scharek R (1997) Physical anatomy of fronts and surface waters in the ACC near the $6^{\circ} \mathrm{W}$ meridian during austral spring 1992. Deep-Sea Res II 44:23-49

Zimmermann R (1977) Estimation of bacterial numbers and biomass by epifuorescence microscopy and scanning electron microscopy. In: Rheinheimer G (ed) Microbial ecology of a brackish water environment. Ecological studies, Vol 25. Springer Verlag, Berlin, p 103-120

Submitted: August 10, 1998; Accepted: June 23, 1999 Proofs received from author(s): November 22, 1999 